\title{
Strength of the Iberian intraplate lithosphere: Cenozoic deformations and seismicity
}

\author{
S. Martín-Velázquez ${ }^{1, *}$, G. de Vicente ${ }^{2,3}$, D. Gómez-Ortiz ${ }^{1}$, F.J. Elorza ${ }^{4}$ \\ ${ }^{1}$ Departamento de Biología y Geología, Física y Química Inorgánica. Universidad Rey Juan Carlos. Móstoles, 28933 Madrid, Spain \\ ${ }^{2}$ Departamento de Geodinámica. Universidad Complutense de Madrid. 28040 Madrid, Spain \\ ${ }^{3}$ Instituto de Geociencias. CSIC, UCM. 28040 Madrid, Spain \\ ${ }^{4}$ Departamento de Matemática Aplicada y Métodos Informáticos. Universidad Politécnica de Madrid. 28003 Madrid, Spain. \\ e-mail addresses: silvia.martin@urjc.es (S.M.V.; *corresponding author); gdv@geo.ucm.es (G.V.); david.gomez@urjc.es (D.G.O.); franciscojavier. \\ elorza@upm.es (F.J.E.)
}

Received: 27 October 2015 / Accepted: 23 March 2016 / Available online: 30 April 2016

\begin{abstract}
Previous studies about the strength of the lithosphere in the center of Iberia fail to resolve the depth of earthquakes because of the rheological uncertainties. Therefore, new contributions are considered (the crustal structure from a density model) and several parameters (tectonic regime, mantle rheology, strain rate) are checked in this paper to properly examine the role of lithospheric strength in the intraplate seismicity and the Cenozoic evolution. The strength distribution with depth, the integrated strength, the effective elastic thickness and the seismogenic thickness have been calculated by a finite element modelling of the lithosphere across the Central System mountain range and the bordering Duero and Madrid sedimentary basins. Only a dry mantle under strike-slip/extension and a strain rate of $10^{-15} \mathrm{~s}^{-1}$, or under extension and $10^{-16} \mathrm{~s}^{-1}$, causes a strong lithosphere. The integrated strength and the elastic thickness are lower in the mountain chain than in the basins. This heterogeneity has been maintained since the Cenozoic and determine the mountain uplift and the biharmonic folding of the Iberian lithosphere during the Alpine deformations. The seismogenic thickness bounds the seismic activity in the upper-middle crust, and the decreasing crustal strength from the Duero Basin towards the Madrid Basin is related to a parallel increase in Plio-Quaternary deformations and seismicity. However, elasto-plastic modelling shows that current African-Eurasian convergence is resolved elastically or ductilely, which accounts for the low seismicity recorded in this region.
\end{abstract}

Keywords: lithospheric strength, effective elastic thickness, seismogenic thickness, Iberia, finite element modelling

\section{Resumen}

Los estudios previos sobre resistencia de la litosfera en el centro de Iberia no logran resolver la profundidad de los terremotos debido a las incertidumbres reológicas. Por eso, en este trabajo se han considerado nuevas contribuciones (estructura cortical obtenida de un modelo de densidad) y se han comprobado varios parámetros (régimen tectónico, reología del manto, tasa de deformación) para examinar adecuadamente el papel de la resistencia de la litosfera en la sismicidad intraplaca y en la evolución Cenozoica. Mediante una modelización de elementos finitos, se ha calculado la distribución de la resistencia con la profundidad, la resistencia integrada, el espesor elástico efectivo y el espesor sismogénico en una sección litosférica que atraviesa la cadena montañosa del Sistema Central y las cuencas sedimentarias del Duero y Madrid. Sólo un manto seco en desgarre/extensión y una tasa de deformación de $10^{-15} \mathrm{~s}^{-1}$, o bajo extensión y $10^{-16} \mathrm{~s}^{-1}$, origina una litosfera resistente. La resistencia integrada y el espesor elástico son más bajos en el sistema montañoso que en las cuencas. Estas anisotropías se han mantenido desde el Cenozoico y determinan el levantamiento de la cadena y el plegamiento biarmónico de la litosfera Ibérica durante las deformaciones alpinas. El espesor sismogénico limita la actividad sísmica en la corteza superior-media, y la disminución de la resistencia cortical desde la Cuenca del Duero hacia la Cuenca de Madrid está relacionada con un aumento paralelo de las deformaciones Plio-Cuaternarias y de la sismicidad. Sin embargo, la modelización elastoplástica muestra que la convergencia Eurasiática-Africana actual se resuelve de forma elástica o dúctil, lo que explica la baja sismicidad registrada en esta región. 


\section{Introduction}

The centre of the Iberian Peninsula is an intraplate region far from the active African-Eurasian plate boundary to the south. Its distinctive features are a Variscan basement uplifted during the Cenozoic (the Central System Range) bounded by two continental basins (the Duero and Madrid basins) (Fig. 1) (Vegas et al. 1990; De Vicente et al. 2007). The stress regime is complex and seismicity is low to moderate (De Vicente et al. 1996; Herraiz et al. 2000; De Vicente et al. 2007; Giner-Robles et al. 2012). Several studies have addressed the estimate of lithospheric strength to explain these characteristics (Van Wees et al., 1996; Gómez-Ortiz 2001; Tejero and Ruiz 2002; Gómez-Ortiz et al., 2005b; Pérez-Gussinyé and Watts 2005; Fernández et al., 2008; Jiménez-Díaz et al., 2012). Although strength strongly depends on the structure, temperature, composition, strain rate and stress regime of the lithosphere (Fernàndez and Ranalli 1997; Afonso and Ranalli 2004; Ruiz et al., 2006; Fernández-Ibáñez and Soto 2008; Burov 2011; Jiménez-Díaz et al., 2012), average crustal and mantle structures over large areas, diverse lithologies (hard/ soft) and stress regimes (compression/tension) were assumed in those previous studies. Consequently, these strength estimates are varied, and even shallow crustal ductile levels or brittle-ductile transitions are obtained that do not totally explain the intraplate seismicity.

In order to constrain some of these factors and the related lithospheric strength, recent contributions are considered in the present work. Since the lithosphere in the peninsular centre varies laterally (Gómez-Ortiz et al., 2005a), its strength will be determined along a detailed cross section to the Central System and bordering basins, solving the thermomechanical equations with a finite element software (ANSYS, http:// www.ansys.com). Although, dry and wet dislocation creep were previously assumed for the upper crust (Tejero and Ruiz, 2002; Ruiz et al., 2006; Jiménez-Díaz et al., 2012), the numerical modelling of Cenozoic deformations discards a weak upper crust (Martín-Velázquez and De Vicente, 2012), and only dry rheology will be modelled in this layer. Other uncertainties, such as tectonic regime, mantle rheology and strain rate, cannot be initially set, and they will be checked through the numerical analysis. In addition, it is interesting to understand not only how permanent deformation is solved across the lithosphere but which regions are actually under reversible and permanent deformation. Therefore, the elastic/ permanent deformation will be also analysed taking into account the current intraplate tectonic stress transmitted from the African-Eurasian boundary.

The following aims have been reached in this work: a) to achieve a more precise understanding of the Iberian intraplate lithospheric strength by reducing uncertainties and selecting results consistent with the geological and geodynamic evidences, b) to identify the relative contribution of crust and mantle in the behaviour of the lithosphere, and c) to relate the strength estimates to the Cenozoic evolution and the current seismicity. In order to achieve these aims, strength models/ envelopes, crustal/mantle/lihospheric integrated strengths, effective elastic thickness and seismogenic thickness have been estimated along a profile with wet/dry mantle rheology, under compressional/shear/tensional stress regimes, and strain rates of $10^{-15}-10^{-17} \mathrm{~s}^{-1}$. The depth distribution of seismicity record has also been analysed, only considering those earthquakes with low location errors.

\section{The Iberian intraplate lithosphere: geological and geophysical background}

\subsection{The Central System and the Duero and Madrid basins}

The Central System is a crustal pop-up in the centre of the Iberian Peninsula with an uplifted Variscan basement (Fig. 1). It is a double vergence chain with thick-skin tectonics and a complex evolution during the Cenozoic (Vegas et al., 1990; Ribeiro et al., 1990; De Vicente et al., 1996; Andeweg et al. 1999; De Vicente et al., 2007). The basement uplift extends for over $500 \mathrm{~km}$ toward the Atlantic coast, with an orientation ranging from $\mathrm{E}-\mathrm{W}$ to $\mathrm{NE}-\mathrm{SW}$ and an average width of $\sim 80$ $\mathrm{km}$. The Central System is located between two Cenozoic continental sedimentary basins, the Duero Basin to the North and the Madrid Basin to the South. Both behaved as flexural foreland basins and their borders are mainly delimited by large crustal thrusts.

The Cenozoic tectonic evolution occurred in a compressive context triggered by the Eurasia-Iberia and Iberia-Africa collisions (Alpine orogeny). Deformations were caused by NW-SE compressive stresses originated at the northern Iberian active border during the Pyrenean collision (PalaeogeneEarly Miocene), and N-S compressive stresses at the southern border during the Betic collision (Neogene) (De Bruijne and Andriessen, 2002; De Vicente et al., 2007; De Vicente and Vegas, 2009). The topography of the mountains and the basements of the bordering basins, as well as the present-day crustal and lithospheric structure, are maintained by large-scale folding and crustal thickening (Martín-Velázquez and De Vicente, 2012). Quaternary palaeoseismic structures have been recognised in the Madrid Basin (Rodríguez-Pascua 2005; Giner-Robles et al., 2012) but the seismicity is moderate to low and it is restricted to a depth of $\sim 15 \mathrm{~km}$ (De Vicente et al. 1996; Herraiz et al., 2000; Tejero and Ruiz, 2002; De Vicente et al., 2007, 2008; Giner-Robles et al., 2012). In the Iberian Peninsula, the active tectonic regime changes from a thrustfault regime in its SW corner to a normal-fault regime in its NE corner (Jiménez-Munt and Negredo, 2003; De Vicente et al., 2008; Olaiz et al., 2009). These two zones are linked by a complex region, where the Central System and the basins are located, under strike-slip to uniaxial extensional stress regime and where the intermediate and maximum principal stresses permute from the NW-SE horizontal axis to the vertical. 

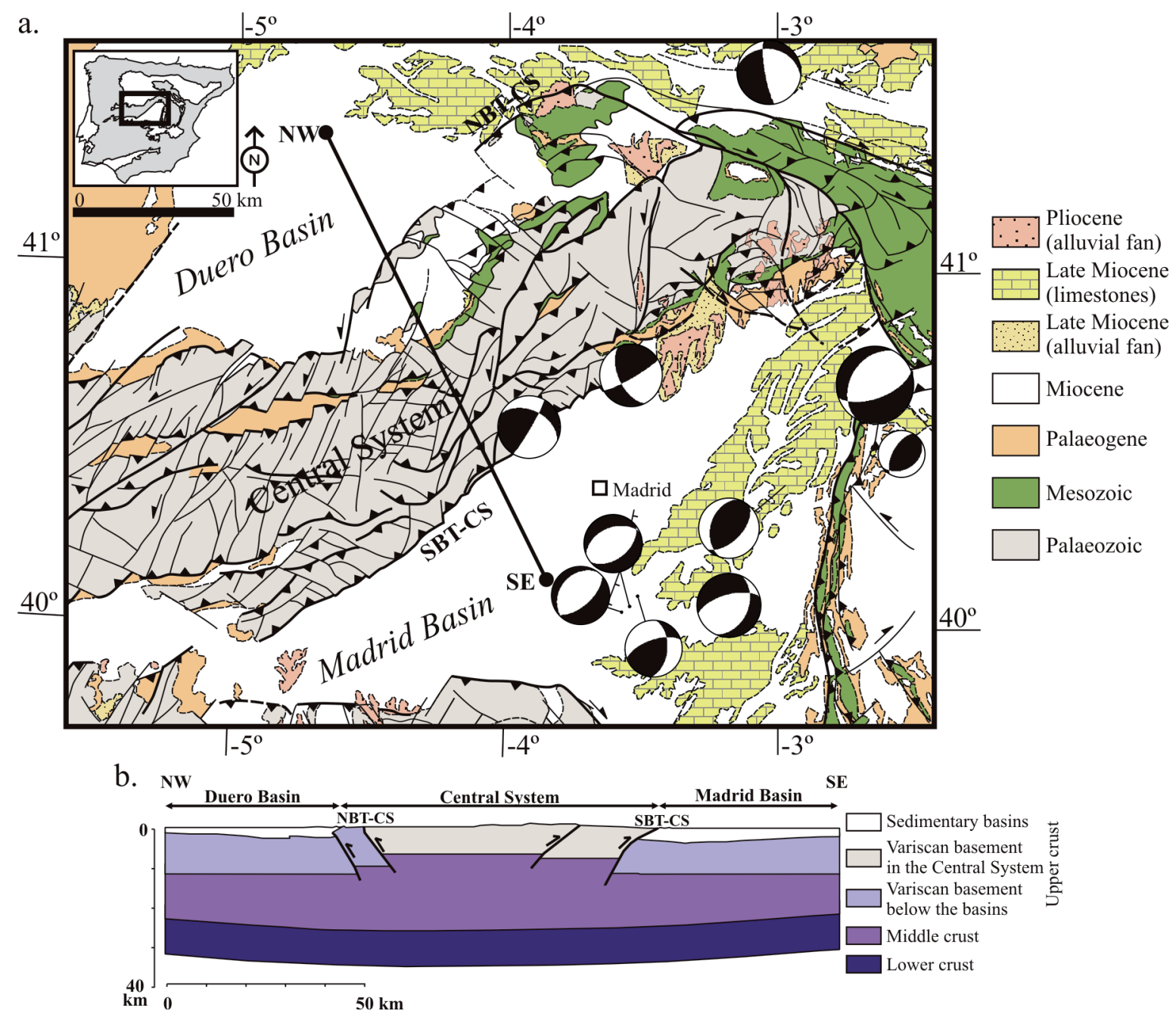

Fig. 1.- (a) Geological sketch of the Central System, the Duero Basin and the Madrid Basin, with the distribution of focal mechanisms (modified from De Vicente et al., 2007). NBT-CS: Northern Border Thrusts of the Central System; SBT-CS: Southern Border Thrust of the Central System. NW-SE black line: modelled lithospheric profile. Top left corner: location of the study zone (box), the Alpine mountain ranges (grey tones) and basins (white) within the Iberian Peninsula. (b) Simplified crustal cross section (location in Fig. 1a) (modified from Gómez-Ortiz et al., 2005a).

\subsection{Structure, composition and heat flow}

The crust in the Iberia interior has an average thickness of 30-31 km (Fig. 1b): an 11-14 km thick upper crust, a 7-12 $\mathrm{km}$ thick middle crust and a 7-9 km thick lower crust (Banda et al., 1981; Suriñach and Vegas, 1988; ILIHA DSS Group, 1993). The crustal thickness increases up to $34-36 \mathrm{~km}$ under the Central System (Suriñach and Vegas, 1988; ILIHA DSS Group 1993; Tejero et al., 1996; Gómez-Ortiz et al., 2005a; De Vicente et al., 2007) because of the buckling of the upper and lower crust by the Alpine compressive stresses (mainly Pyrenean) (Suriñach and Vegas 1988; Martín-Velázquez and De Vicente, 2012). The sedimentary cover has a thickness of $\sim 2500 \mathrm{~m}$ in the Duero Basin (Gómez-Ortiz et al. 2005a; De Vicente et al., 2007), while it reaches $\sim 3400 \mathrm{~m}$ in the Madrid basin (Racero Baena 1988; Querol Müller 1989; Tejero et al. 1996; Gómez-Ortiz et al. 2005a; De Vicente et al., 2007; De Vicente and Muñoz,Martín, 2012). The lithosphere-astheno- sphere boundary is located at a mean depth of $\sim 100 \mathrm{~km}$ in the peninsular interior (Banda et al., 1981; Fernàndez et al., 1998; Tejero and Ruiz 2002; Fernández et al., 2008; MartínVelázquez and De Vicente, 2012).

Different petrological (Racero Baena, 1988; Villaseca et al., 1999; Alonso-Gavilán et al., 2004; Alonso-Zarza et al., 2004; Ancochea, 2004; Bea et al., 2004; Villaseca and Orejana, 2008), gravimetric (Gómez-Ortiz et al., 2005a), seismic (Banda et al. 1981; Querol Müller 1989), teleseismic (Julià and Mejía, 2004), and rheological (Tejero and Ruiz, 2002) studies provide information about the prevailing lithologies of the lithospheric layers. Sedimentary materials gradually change from siliciclastic at the boundaries of the Duero and Madrid basins to evaporitic in the central areas. The nature of the upper crust is granite-metamorphic in the Central System and metamorphic under the basins. Finally, the middle crust is granodioritic, the lower crust is felsic granulitic, and the mantle is peridotitic. 
The surface heat flow ranges from 60 to $85 \mathrm{~mW} \mathrm{~m}^{-2}$, with the highest values in the Central System (Fernàndez et al., 1998; Jiménez-Díaz et al., 2012). The heat production in the upper crust ranges from $0.2-4.7 \mu \mathrm{W} \mathrm{m} \mathrm{m}^{-3}$ in the granitic rocks and from $0.8-2.3 \mu \mathrm{W} \mathrm{m}{ }^{-3}$ in the metamorphic rocks (Fernàndez et al. 1998; Jiménez-Díaz et al., 2012), whereas it barely exceeds $1 \mu \mathrm{W} \mathrm{m}{ }^{-3}$ in the lower crust (Villaseca et al., 1999, 2005; Jiménez-Díaz et al., 2012).

\subsection{Previous estimates of the lithospheric strength}

Over the past years, the rheological behaviour of the Iberian intraplate has been characterised by the construction of strength envelopes (Gómez-Ortiz, 2001; Tejero and Ruiz, 2002; Jiménez-Díaz et al., 2012) as well as 2D cross sections of lithospheric strength (Martín-Velázquez et al., 2008). These tectonic units define three rheological domains, with greater differential stresses in the Duero Basin and lower in the Central System. According to Tejero and Ruiz (2002), brittle-ductile transitions develop in the crust (one in compression and two in tension), while deformation is fundamentally ductile in the mantle. The lithospheric integrated strength is in the range of $1.3-8 \times 10^{12} \mathrm{~N} \mathrm{~m}^{-1}$ (Tejero and Ruiz 2002), although later estimates increase the values by an order of magnitude (Fernández et al., 2008).

Lithospheric strength has also been studied from the effective elastic thickness with various methodologies. $T_{e}$ have been limited by flexure modelling to $7 \mathrm{~km}$ in the Madrid Basin (Van Wees et al., 1996), and by Bouguer coherence and free-air admittance methods to $15-30 \mathrm{~km}$ and $30-40 \mathrm{~km}$, respectively, for the entire centre of Iberia (Gómez-Ortiz et $a l ., 2005 b$; Pérez-Gussinyé and Watts, 2005). The strength envelopes provide different estimates for the basins and the Central System (Gómez-Ortiz et al., 2005b): $17 \mathrm{~km} / \sim 26.5$ $\mathrm{km}$ (wet/dry rheologies) and $13 \mathrm{~km} / 22 \mathrm{~km}$ (wet/dry rheologies) respectively. A decrease is also observed in the $\rightarrow \cdot$ map of the European lithosphere, from $35-40 \mathrm{~km}$ in the interior of the basins up to $5-10 \mathrm{~km}$ in the mountain range (Tesauro et al., 2007). However, more recent estimates show a less marked variation of $T_{e}$ between the three units, with differences of only 1-2 km (Martín-Velázquez et al., 2008; Jiménez-Díaz et al., 2012).

\section{Model setup}

\subsection{Thermomechanical equations}

The strength and deformation models were estimated with the finite element code ANSYS. First, the temperature distribution and heat flow were solved in a thermal analysis [1-2]. Then, the lithospheric strength was calculated [3-4] and included as a nonlinear material parameter (stress at which yielding is initiated) in the software pre-processor. Theoretical concepts on stable geotherms define the thermal structure (Ranalli, 1995; Turcotte and Schubert, 2002): a) the heat is transported by conduction [1] and b) the radiogenic heat production decreases exponentially with depth [2].

$$
\begin{aligned}
& k\left(d^{2} T / d y^{2}\right)=-S \\
& S_{(y)}=S_{0} \exp ^{(-y / D)}
\end{aligned}
$$

where $k$ is the thermal conductivity, $T$ is the temperature, $y$ is the depth, $S$ is the heat production, $S_{0}$ is the heat production at the layer top, and $D$ is the exponential decay constant.

The strength models were based on the calculation of two mechanisms of deformation (Ranalli, 1995; Turcotte and Schubert, 2002): a) linear increase of the brittle strength with depth by frictional sliding [3], and b) exponential decay of the viscous strength with depth according to dislocation creep [4]:

$$
\begin{aligned}
& \sigma_{d}=\alpha \rho g y(1-\lambda) \\
& \sigma_{d}=(\dot{\varepsilon} / A)^{(1 / n)} \exp ^{(Q / n R T)}
\end{aligned}
$$

where $\sigma_{d}$ is the differential stress, $\alpha$ is the parameter depending on the type of faulting, $\rho$ is the density of rocks, $g$ is the gravity acceleration, $y$ is the depth, $\lambda$ is the pore fluid factor, $\dot{\varepsilon}$ is the strain rate, $A$ and $n$ are the material constants, $Q$ is the activation enthalpy for creep, $R$ is the gas constant, and $T$ is the temperature. After calculating the brittle and ductile mechanism for each element of the mesh, the strength was finally defined by the smaller value.

The following parameters were calculated from 2D strength models: a) the integrated strength $F$ of the crust, mantle and lithosphere, calculated from the integration of strength models [5], b) the effective elastic thickness of the lithosphere without flexure $T_{e}$ [6] (Burov and Diament, 1995; Watts and Burov, 2003), and c) the seismogenic thickness $T_{s}$ that extends up to the most shallow brittle-ductile transition of the strength envelopes (Watts and Burov, 2003):

$$
\begin{aligned}
& F=\int_{0}^{y_{l}} \sigma_{d} d y \\
& T_{e}=\left(\sum_{i=1}^{n} h_{i}^{3}\right)^{1 / 3}
\end{aligned}
$$

$T_{e}$ was calculated for a lithosphere made up by $n$ layers, whose mechanical thicknesses are equal to $h$. The base of a mechanical layer was defined by the depth at which the strength decreases up to $10 \mathrm{MPa}$ (Burov and Diament, 1995). $T_{e}$ is the thickness of the entire elastic layer of the lithosphere that deforms to long-term geological loads $\left(>10^{5} \mathrm{yr}\right)$, whereas $T_{s}$ is the thickness of the uppermost brittle layer that responds on historical time scales to stresses by faulting and earthquakes (Watts and Burov, 2003).

Finally, the current deformation mechanisms of the lithosphere were obtained following the procedure of Moisio and 
Kaikkonen $(2001,2004)$ by modelling its elasto-plastic behaviour from the von Mises criterion $\sigma_{0}$ [7]:

$$
2 \sigma_{0}^{2}=\left(\sigma_{1}-\sigma_{2}\right)^{2}+\left(\sigma_{2}-\sigma_{3}\right)^{2}+\left(\sigma_{1}-\sigma_{3}\right)^{2}
$$

where, $\sigma_{1}, \sigma_{2}, \sigma_{3}$ are the principal stresses. The lithosphere deforms elastically or permanently, and the permanent (plastic) deformation takes place once the loads generate stresses that exceed its brittle or viscous strength. As stress magnitudes resulting from only time-independent strains were evaluated, this simplification of the deformation mode is appropiate. A tectonic load was applied in both lateral sides, and the yielding relation $R=\sigma_{e} / \sigma_{c}$ was computed. The equivalent stress $\sigma_{e}$, which describes the tectonic stress, is the square root of the second invariant of the stress tensor. The yield stress $\sigma_{c}$, from which permanent deformation occurs, was defined by the previously calculated strength [3-4]. Therefore, regions with $R \geq 1$ are brittle or ductile, while those with $R<1$ are elastic. Small strains are elastic until the yield strength is exceeded, and they were estimated under plane strain $\left(\varepsilon_{3}=0\right)$ [8-10] (Ranalli 1995; Turcotte and Schubert, 2002):

$$
\begin{aligned}
& \varepsilon_{1}=\frac{(1+v)}{E}\left\{\sigma_{1}(1-v)-v \sigma_{2}\right\} \\
& \varepsilon_{2}=\frac{(1+v)}{E}\left\{\sigma_{2}(1-v)-v \sigma_{1}\right\} \\
& \sigma_{3}=v\left(\sigma_{1}+\sigma_{2}\right)
\end{aligned}
$$

where $\varepsilon_{1}, \varepsilon_{2}, \varepsilon_{3}$ are the principal strains, $v$ is the Poisson's ratio, and $E$ is the Young's modulus.

\subsection{Model and material parameters}

The numerical model represents the lithosphere of the centre of Iberia (Central System and Duero and Madrid basins) along a cross section transverse to the major Alpine thrusts and parallel to the active maximum horizontal stress (Figs. 1 and2). The crustal structure was synthesised from a density model in the eastern sector of the Central System (GómezOrtiz et al., 2005a). The lithosphere-asthenosphere boundary has a concave geometry because of the folding of the base of the Iberian intraplate lithosphere during the Cenozoic (Martín-Velázquez and De Vicente, 2012). Three sectors were differentiated from NW to SE with distinct composition in the upper crust and thermal structure in the lithosphere: Duero Basin, Central System and Madrid Basin.

The mechanical and thermal properties were defined from different studies in the peninsular centre (Table 1). According to the complex stress conditions in the peninsular centre, brittle strength [3] was calculated in thrust, strike-slip and normal fault regimes, and thus $\alpha$ was respectively 3.0, 1.2 and 0.75 , assuming a coefficient of friction 0.75 (Ranalli, 1995). A hydrostatic pore fluid pressure $P_{f}$ was assumed in
$\lambda=P_{f} / \sigma_{v}$, and variations of density with depth were included when calculating the lithostatic load $\sigma_{v}$. A low density was used in the Central System upper crust because of the abundance of granitic lithologies as a result of the extensive Variscan plutonism, while the density of Cenozoic sediments was averaged from Gómez-Ortiz et al. (2005a) (Table 1). Regarding the viscous strength [4], $\dot{\varepsilon}$ was ranged from $10^{-15}$ $\mathrm{s}^{-1}$ to $10^{-17}$ (Tejero and Ruiz, 2002; Jiménez-Díaz et al., 2012), and $T$ was taken from the previous calculation of the thermal structure. Dislocation creep parameters are representative of the characteristic lithologies in this area (Table 1). Dry rheologies were selected in the upper crust from Cenozoic deformation modelling (Martín-Velázquez and De Vicente, 2012), and as mantle composition is not constrained (Ruiz et al. 2006), the two extreme cases were checked: dry and wet lithospheric mantle.

\subsection{Boundary conditions}

An exponential decay of heat generation for each layer was assumed in the thermal analysis, except for the sedimentary basins in which a constant value was applied (Table 1). Constant temperatures were defined at the surface $\left(15^{\circ} \mathrm{C}\right)$ and the base $\left(1350{ }^{\circ} \mathrm{C}\right)$ of the model (Tejero and Ruiz, 2002; Ruiz et al., 2006) (Fig. 2).

The strength models obtained from the combination of the three stress regimes with the two rheologies were used as $\sigma_{c}$ in the deformation analysis. The tectonic stress in the Iberian interior originated by tectonic forces acting along the Eurasian-African boundary plate $\left(0.1-1.5 \times 10^{12} \mathrm{~N} \mathrm{~m}^{-1}\right)$, the lithospheric integrated strength $\left(1.5-3 \times 10^{12} \mathrm{~N} \mathrm{~m}^{-1}\right)$ and the peculiarities of the tectonic regime in the peninsular centre (Gölke and Coblentz 1996; Andeweg, 2002; Tejero and Ruiz, 2002; Jiménez-Munt and Negredo, 2003; De Vicente et al., 2008) suggest that the current tectonic stress in the Iberian Peninsula should be close to $\sim 10 \mathrm{MPa}$ without exceeding 25 MPa (Martín-Velázquez et al., 2009). Consequently, the models were deformed by a constant pressure of $10 \mathrm{MPa}$ in each of both lateral sides (Fig. 2), so the estimated strain regimes (elastic/permanent) are the result of only tectonic loads. The vertical displacement of the base nodes was restricted and the horizontal movement of the node located halfway in the base was also fixed for the models to be in equilibrium.

\section{Thermal structure}

In this section, the results of the thermal modelling in the Iberian intraplate lithosphere are described. The temperature and heat flow distributions are subparallel to the surface, although lateral variations occur owing to the lithospheric heterogeneities (topography, crustal thickness, thermal parameters, heat production). The Central System sector has the highest temperature in the crust-mantle boundary and the surface heat flow (Fig. 3). Temperature increases from $\sim 600$ ${ }^{\circ} \mathrm{C}$ in the lateral sides $\left(611{ }^{\circ} \mathrm{C}\right.$ in the Duero Basin and $596{ }^{\circ} \mathrm{C}$ 


\begin{tabular}{|c|c|c|c|c|c|c|c|c|c|}
\hline \multirow[b]{2}{*}{$\begin{array}{l}\text { Lithospheric } \\
\text { unit }\end{array}$} & \multirow[b]{2}{*}{$\begin{array}{l}\text { Density* } \\
\left(\mathrm{kg} \mathrm{m}^{-3}\right)\end{array}$} & \multirow{2}{*}{$\begin{array}{c}\text { Heat } \\
\text { production } \dagger \\
\left(\mu \mathrm{W} \mathrm{m}{ }^{-3}\right)\end{array}$} & \multicolumn{2}{|c|}{ Elastic parameters $\ddagger$} & \multicolumn{4}{|c|}{ Creep parameters $\S$} & \multirow{2}{*}{$\begin{array}{c}\text { Thermal } \\
\text { parameter- }\end{array}$} \\
\hline & & & $\begin{array}{l}\text { Young's } \\
\text { modulus } \\
(\mathrm{Pa})\end{array}$ & $\begin{array}{l}\text { Poisson's } \\
\text { ratio }\end{array}$ & Lithology & $\begin{array}{c}\mathrm{A} \\
\left(\mathrm{MPa}^{-\mathrm{n}} \mathrm{s}^{-1}\right)\end{array}$ & $\mathrm{n}$ & $\begin{array}{c}\mathrm{E} \\
\left(\mathrm{kJ} \mathrm{mol}^{-1}\right)\end{array}$ & \\
\hline Sediments & 2300 & 2.5 & $20 \times 10^{9}$ & 0.25 & Dry quartzite & $6.7 \times 10^{-6}$ & 2.4 & 156 & 2.5 \\
\hline Central System upper crust & 2670 & $3.3 \exp ^{(-y / 12)}$ & $75 \times 10^{9}$ & 0.26 & Dry granite & $1.8 \times 10^{-9}$ & 3.2 & 123 & 2.5 \\
\hline Duero basin upper crust & 2780 & $1.8 \exp ^{(-y / 12)}$ & $75 \times 10^{9}$ & 0.26 & Dry quartzite & $6.7 \times 10^{-6}$ & 2.4 & 156 & 2.5 \\
\hline Madrid basin upper crust & 2780 & $2.5 \exp ^{(-y / 12)}$ & $75 \times 10^{9}$ & 0.26 & Dry quartzite & $6.7 \times 10^{-6}$ & 2.4 & 156 & 2.5 \\
\hline Middle crust & 2800 & $\begin{array}{l}\text { Exponential decay } \\
\text { from upper crust }\end{array}$ & $91 \times 10^{9}$ & 0.27 & Quartzdiorite & $1.3 \times 10^{-3}$ & 2.4 & 219 & 2.5 \\
\hline Lower crust & 2900 & $0.8 \exp ^{(-y / 12)}$ & $114 \times 10^{9}$ & 0.26 & Felsic granulite & $8.0 \times 10^{-3}$ & 3.1 & 243 & 2.1 \\
\hline Lithospheric mantle (dry) & 3300 & $0.02 \exp ^{(-y / 12)}$ & $172 \times 10^{9}$ & 0.28 & Dry peridotite & $2.5 \times 10^{4}$ & 3.5 & 532 & 3.4 \\
\hline Lithospheric mantle (wet) & 3300 & $0.02 \exp ^{(-y / 12)}$ & $172 \times 10^{9}$ & 0.28 & Wet peridotite & $2.0 \times 10^{3}$ & 4.0 & 471 & 3.4 \\
\hline
\end{tabular}

*Taken from Gómez-Ortiz et al. (2005a).

$\dagger$ Taken from Fernàndez et al. (1998), Villaseca et al. (1999) and Tejero \& Ruiz (2002).

\$Calculated from seismic-wave velocities (Banda et al. 1981) and densities (Gómez-Ortiz et al. 2005a) (see for details Martín-Velázquez \& De

Vicente, 2012).

§Taken from Ranalli (1995),

ๆTaken from Fernàndez et al. (1998) and Tejero \& Ruiz (2002).

Table 1.- Thermomechanical parameters.

in the Madrid Basin) up to $\sim 650{ }^{\circ} \mathrm{C}$ below the Central System. The surface heat flow is characterised by fluctuations in its magnitude: $59-63 \mathrm{~mW} \mathrm{~m}^{-2}$ in the Duero Basin, $49-77 \mathrm{~mW}$ $\mathrm{m}^{-2}$ in the Central System and $63-72 \mathrm{~mW} \mathrm{~m}^{-2}$ in the Madrid Basin. Although the mountain range exhibits the extreme values, its mode $\left(68 \mathrm{~mW} \mathrm{~m}^{-2}\right)$ is the same as in the Madrid Basin. The mantle heat flow increases from $33 \mathrm{~mW} \mathrm{~m}^{-2}$ below the central elevations to $\sim 36 \mathrm{~mW} \mathrm{~m}^{-2}$ in the lateral sides, with slightly higher values in the Duero Basin. These results are consistent with the previous studies (Fernàndez et al., 1998; Tejero and Ruiz, 2002; Villaseca et al., 2005; Villaseca and
Orejana, 2008; Fernández et al., 2008; Jiménez-Díaz et al., 2012), and the slight discrepancies are caused by differences in the lithospheric structures and thermal parameters.

\section{Lithospheric strength}

\subsection{Mechanical behaviour and integrated strength}

The strength of the lithosphere was initially calculated for the three stress regimes (compression/thrust fault, shear/ strike-slip fault, tensile/normal fault), both types of mantle

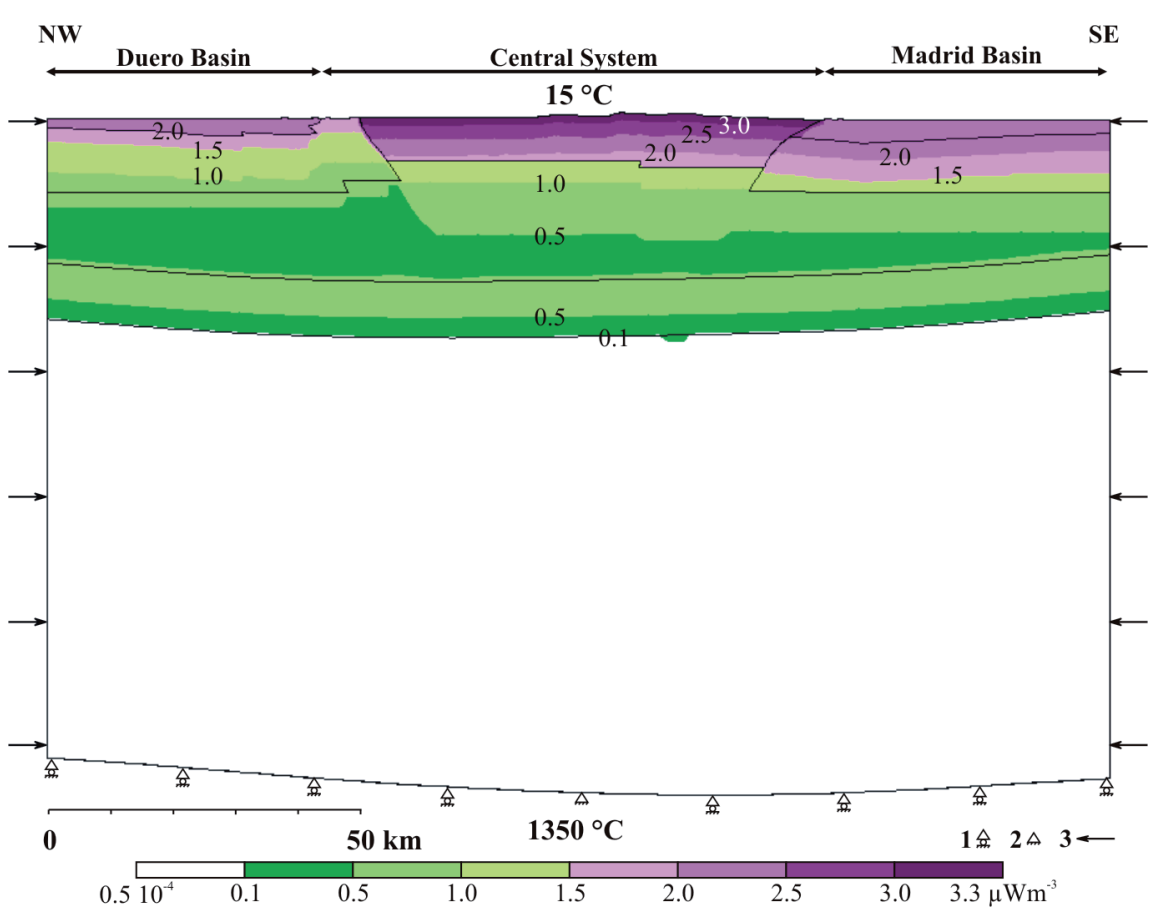

Fig. 2.- Boundary conditions and loads in the thermal and deformation analysis. Black lines: boundaries between lithospheric units. Contour legend: radiogenic heat production. Symbol legend: 1. horizontal displacement, 2. fixed node, 3. horizontal load. 
Fig. 3.- (a) Surface and mantle heat flow. The black dashed line shows the current surface heat flow from Fernàndez et al. (1998). (b) Temperature at crust-mantle boundary. a.
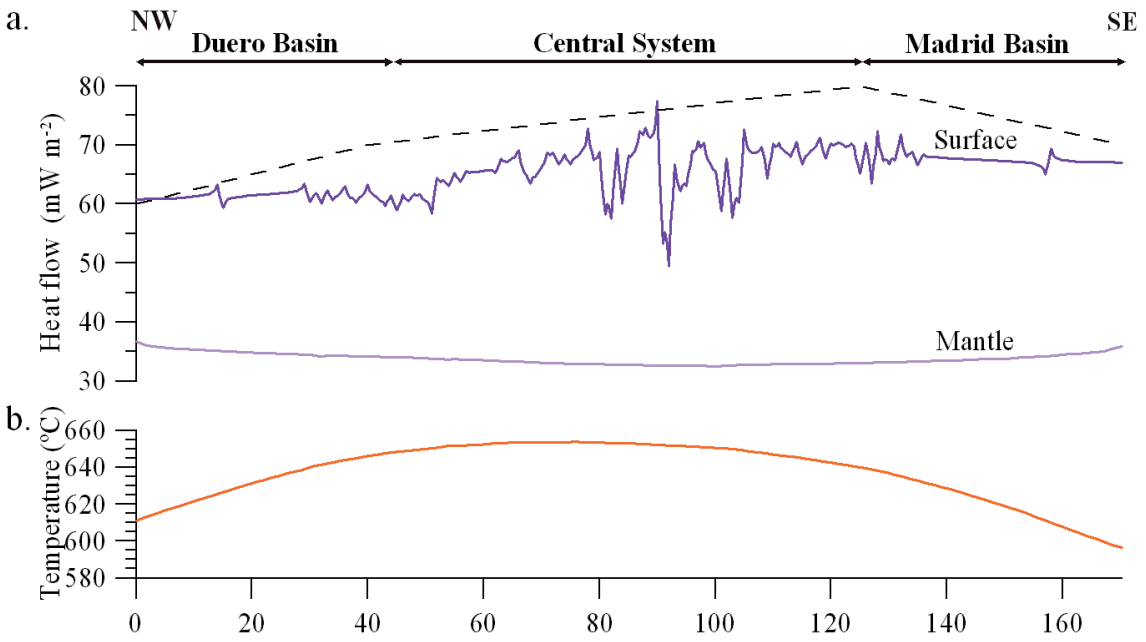

rheology (dry, wet), and a $\dot{\varepsilon}$ of $10^{-15} \mathrm{~s}^{-1}$ (Fig. 4). The contrasts in temperature, composition and crustal thickness produce lateral variations of strength that are more pronounced in dry conditions and compressive regime: $\sim 1350 \mathrm{MPa}$ in the Duero Basin, $\sim 950 \mathrm{MPa}$ in the Central System and $\sim 1550$ $\mathrm{MPa}$ in the Madrid Basin.

The deformation mechanism is brittle in the upper half of the crust and ductile in the lower half (Fig. 4). A thin ductile layer develops within the brittle crustal level of both basins (above the upper-middle crust boundary) under a compressive regime (Fig. 4a, 4d), and to a lesser extent under shear regime (Fig. 4b, 4e). The magnitude and depth of maximum strength in the crust are conditioned essentially by the stress regime: $\sim 750 \mathrm{MPa} / 15 \mathrm{~km}$ in compression, $\sim 350 \mathrm{MPa} / \sim 16$ $\mathrm{km}$ in strike-slip and $\sim 250 \mathrm{MPa} / \sim 18 \mathrm{~km}$ in tension. Although these values remain quite constant along the middle crust of the entire section, some variations are observed as a result of lateral heterogeneities.

The mantle deformation is essentially ductile with its maximum strength at the mantle-crust boundary (Fig. 4). However, the dry mantle may deform in a brittle way near the base of the crust under shear and tensile regimes, and the maximum strength is reached at $\sim 3 \mathrm{~km}$ below the Moho (deeper values under the basins) (Fig. 4b, 4c). The maximum strength of the mantle is greater than the crustal one under dry conditions, whereas it is significantly reduced under wet conditions. The maximum strength/depth decreases/increases from thrust to normal fault regimes with a dry rheology $(\sim 1250 \mathrm{MPa} / 34 \mathrm{~km}$, $\sim 950 \mathrm{MPa} / 36 \mathrm{~km}$ and $\sim 600 \mathrm{MPa} / 38 \mathrm{~km}$ ), although this trend is independent of the stress regime with a wet rheology $(\sim 125$ $\mathrm{MPa} / 34 \mathrm{~km})$.

The integrated strength of the crust, mantle and lithosphere varies from $8.3 \times 10^{11} \mathrm{~N} \mathrm{~m}^{-1}$ to $2.3 \times 10^{13} \mathrm{~N} \mathrm{~m}^{-1}$ (Fig. 5). In general, the magnitudes decrease from compression to tension (wet mantle strength does not depend on the stress regime), and from dry to wet mantle conditions (crustal strength does not depend on the mantle rheology). The mantle and lithospheric strengths in the basins are always higher than in the mountain range. However, crustal strength is lower in the basins in compression and it decreases from NW to SE in shear/ tensile regimes. These lateral differences are conditioned by the strength of the mantle beneath the basins and the ductile layer development in their upper crusts (Fig. 4). The integrated strength of the anhydrous mantle is greater than that of the crust, except in the sector of the Central System under a compressive regime, whereas the opposite situation occurs with a hydrous mantle.

\subsection{Effective elastic thickness}

A mechanical decoupling between the crust and mantle is always obtained. The average competent thicknesses of the crust, the dry mantle and the wet mantle are respectively $\sim 26$, $\sim 30$ and $\sim 19 \mathrm{~km}$. The mechanical crustal layer thickness decreases from NW to SE, while the mechanical mantle layer is somewhat thicker under the basins. These thickness variations cause the effective elastic thickness decreases from the sides of the cross section toward the Central System boundaries, to rise again slightly inside the range (Fig. 4). The Madrid Basin yields the highest $T_{e}$ and the Duero Basin the lowest ones. Furthermore, estimates are higher with a dry mantle: $30-35 \mathrm{~km} v s .22-25 \mathrm{~km}$.

\subsection{Seismogenic thickness}

The seismogenic thickness is determined by the stress regime and lateral heterogeneities of the crust. Its magnitude approximately decreases from extensional to compressive conditions (Fig. 4). The lithosphere displays a brittle-ductile transition very constant laterally under tension $\left(T_{s} \sim 17\right.$ $\mathrm{km}$, although locally can decrease up to $\sim 8 \mathrm{~km}$ ). The brittleductile transition is deeper in the Duero Basin and Central System than in the Madrid Basin in shear regime $\left(T_{s} \sim 17 \mathrm{~km}\right.$ $v s . \sim 10 \mathrm{~km})$. And the predominant depth is considerably reduced under compression $\left(T_{s} \sim 9 \mathrm{~km}\right)$, although deeper values are maintained in the northern half of the Central System ( $T_{s}$ $\sim 15 \mathrm{~km})$. 

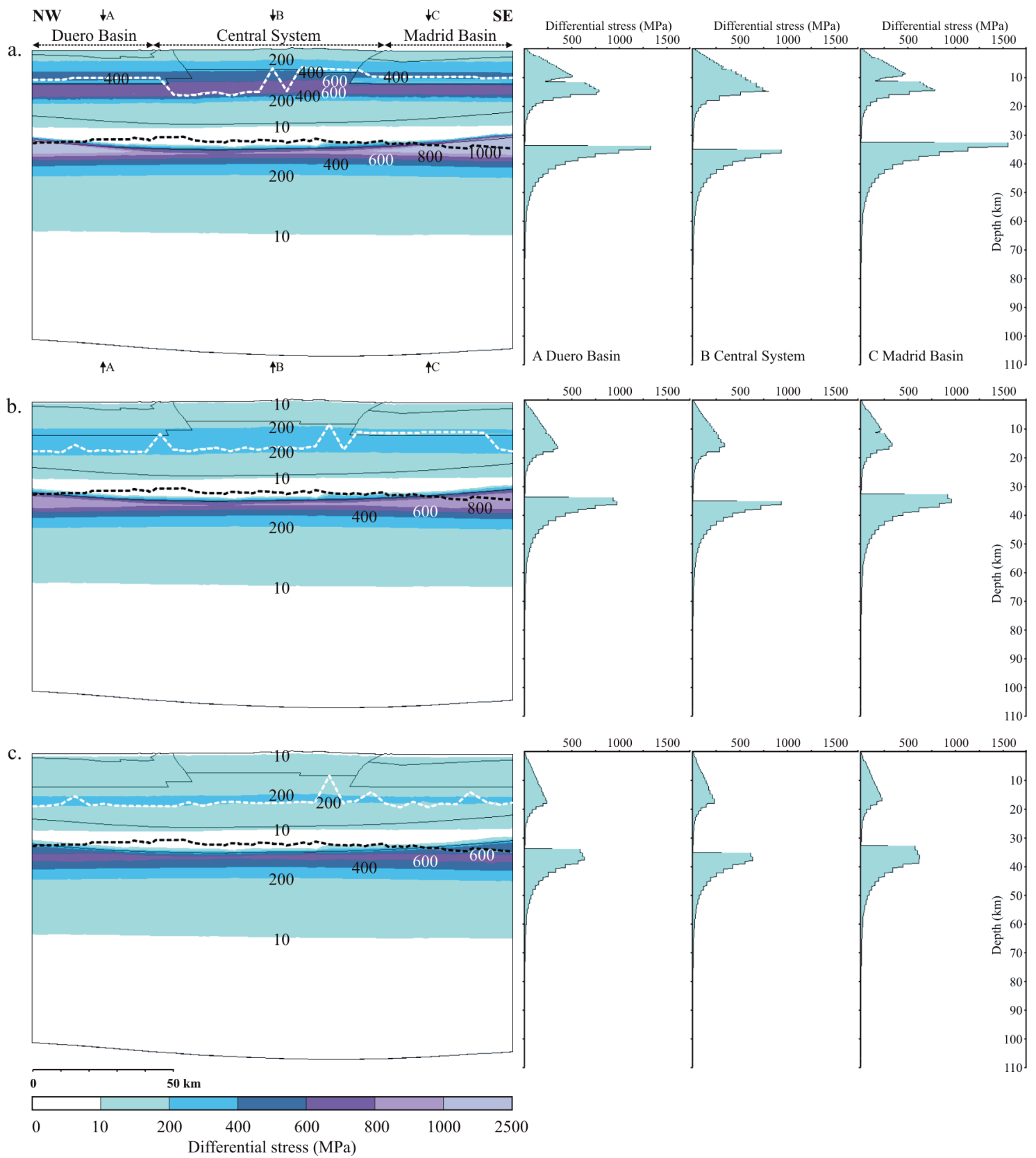

Fig. 4.- 2D strength models of the Iberian intraplate lithosphere and strength envelopes in the Duero Basin (A), Central System (B) and Madrid Basin (C). Dry mantle: (a) compressive regime, (b) shear regime, and (c) tensile regime. Wet mantle: (d) compressive regime, (e) shear regime, and (f) tensile regime. Dashed lines: seismogenic thickness (white), effective elastic thickness (black).

\subsection{Elastic and permanent deformation}

The lithospheric layers decouple under a tectonic load of $10 \mathrm{MPa}$ in each lateral side, regardless of the stress regime and rheological parameters (Fig. 6). Strong layers develop in the upper-middle crust and the upper part of the lithospheric mantle, where the deformation is elastic $(R<1)$. By contrast, the deviatoric stresses exceed the limit of the ductile strength in the lower crust and lower part of the lithospheric mantle $(R \geq 1)$. An increase in the $R$ values is observed near the surface of the models from compressive to tensile regime, so brittle deformation may occur in strike-slip and tension contexts. In addition, the elastic mantle regions are reduced from an anhydrous to a hydrous mantle.

\section{Discussion}

\subsection{The Iberian intraplate rheological model: strong vs. soft mantle}

The lithospheric strength is related to geological processes, and two rheological models with different geodynamic implications have been proposed: lithospheres with strong or dry mantles (the jelly sandwich model; Ranalli and Murphy, 1987; Kohlstedt et al., 1995; Burov and Diament, 1995; Watts and Burov, 2003; Burov and Watts, 2006; Burov 2009, 2011) and lithospheres with soft or wet mantles (the crème brûlée model; Maggi et al., 2000; Jackson 2002; Jackson et al., 2008). Despite the debate between supporters of each model, 

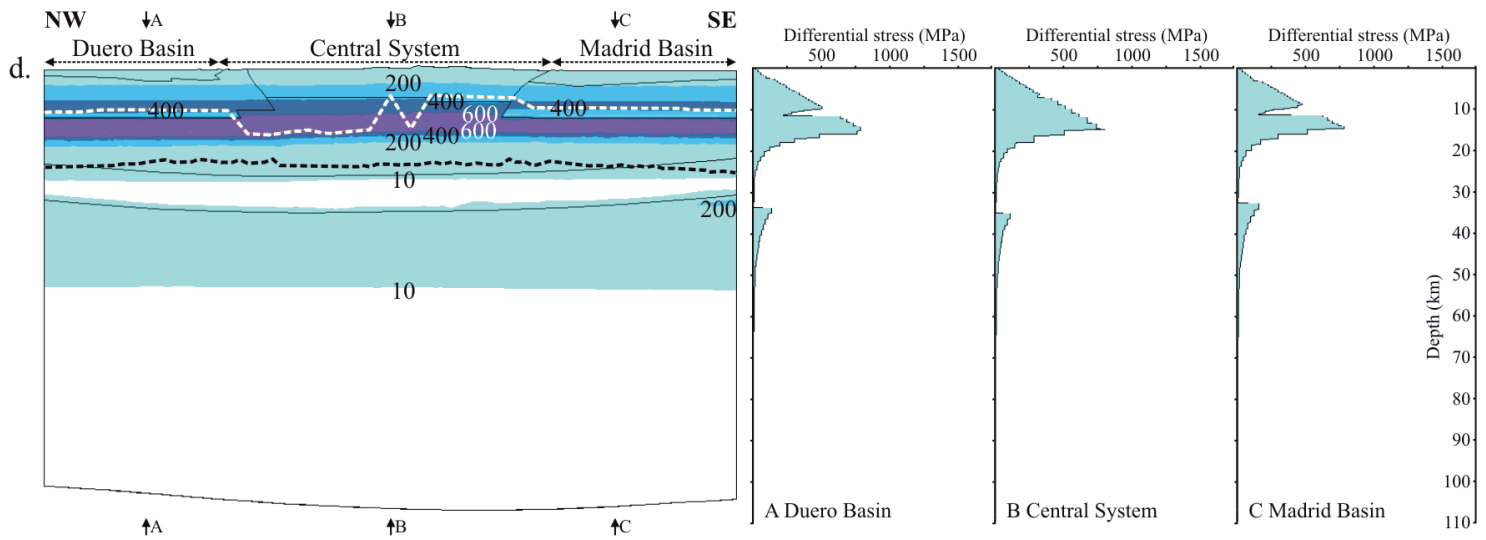

e.
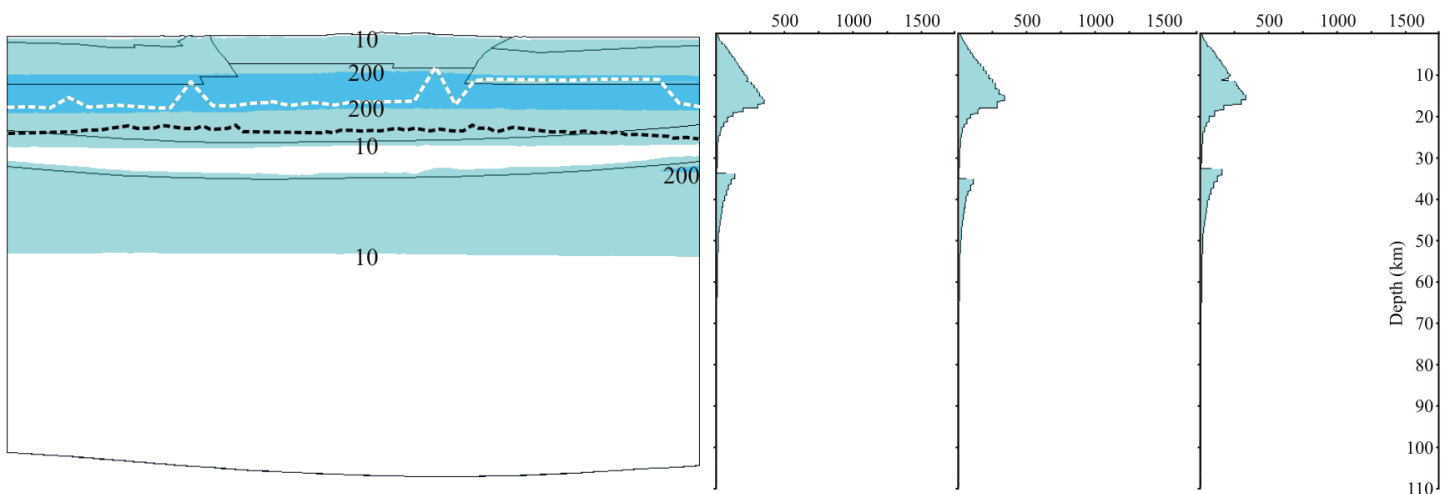

f.
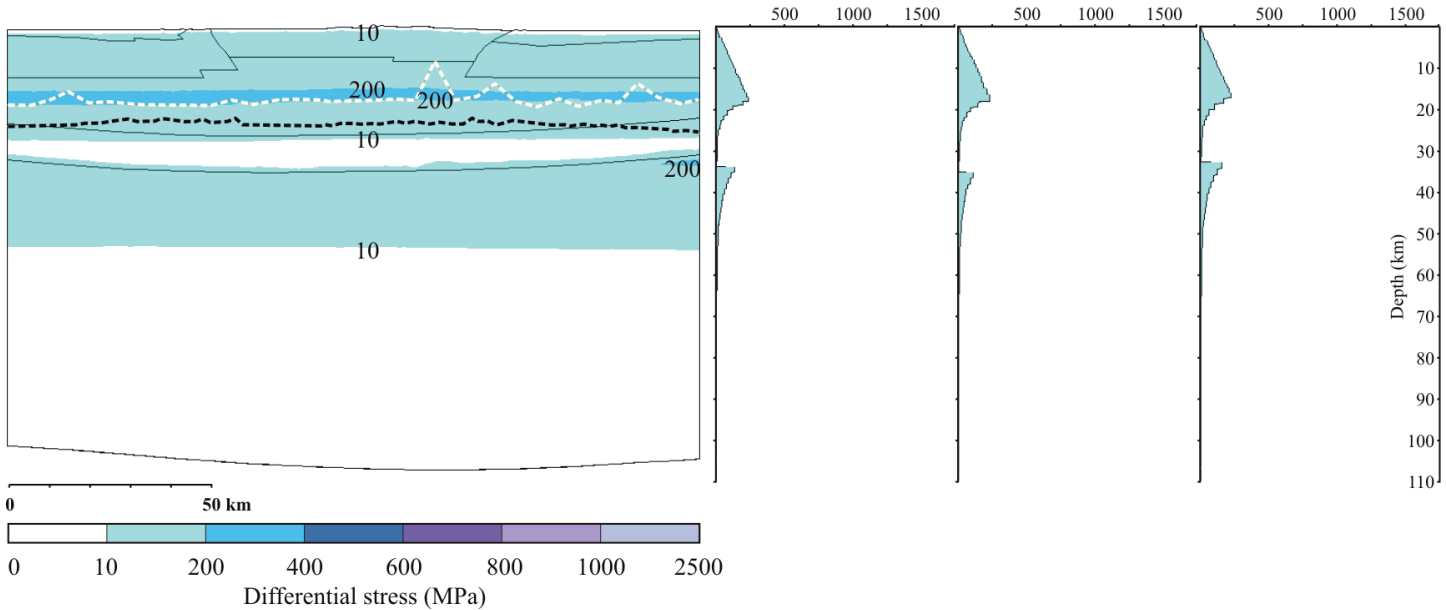

Fig. 4.- (continues from previous page).

only strong mantles can simulate orogenic and subduction processes in visco-elasto-plastic models, since otherwise delamination occurs, and they provide a general framework to explain the maintenance of the main features on the Earth's surface for long periods of time (Burov and Watts, 2006; Burov, 2009, 2011).

Although the mechanical behaviour of the lithosphere greatly depends on the mantle composition, this factor is often difficult to constrain (Fernàndez and Ranalli, 1997; Afonso and Ranalli, 2004; Burov, 2011). Thus, in the Iberian intraplate lithospheric mantle under a tensile regime, a wet rheology is suggested from $T_{e}$ estimates but which contributes significantly to the lithospheric strength: the mantle contribution to $T_{e}$ exceeds 10 times the crust contribution, even to be 40 times larger (Ruiz et al., 2006). However, this result seems to be related to a crust without a rheological stratification, i.e. the middle crust does not contribute to the strength, and the high Young's modulus (100 GPa) assumed for the lithosphere, which possibly drive to an overestimation of the strength values. Moreover, this wet rheology was selected from the upper limit of published $T_{e}(21 \mathrm{~km})$ in this area (see for details Ruiz et al., 2006), but a dry mantle is also possible considering the most recent estimates that reach $30 \mathrm{~km}$.

The lithospheric strength estimated in this work along the Iberian section is very different under anhydrous or hydrated conditions of the mantle (Figs. 4 and6), differing from the above results of Ruiz et al. (2006). It is mainly maintained by the dry peridotitic mantle (crustal strength is higher only 

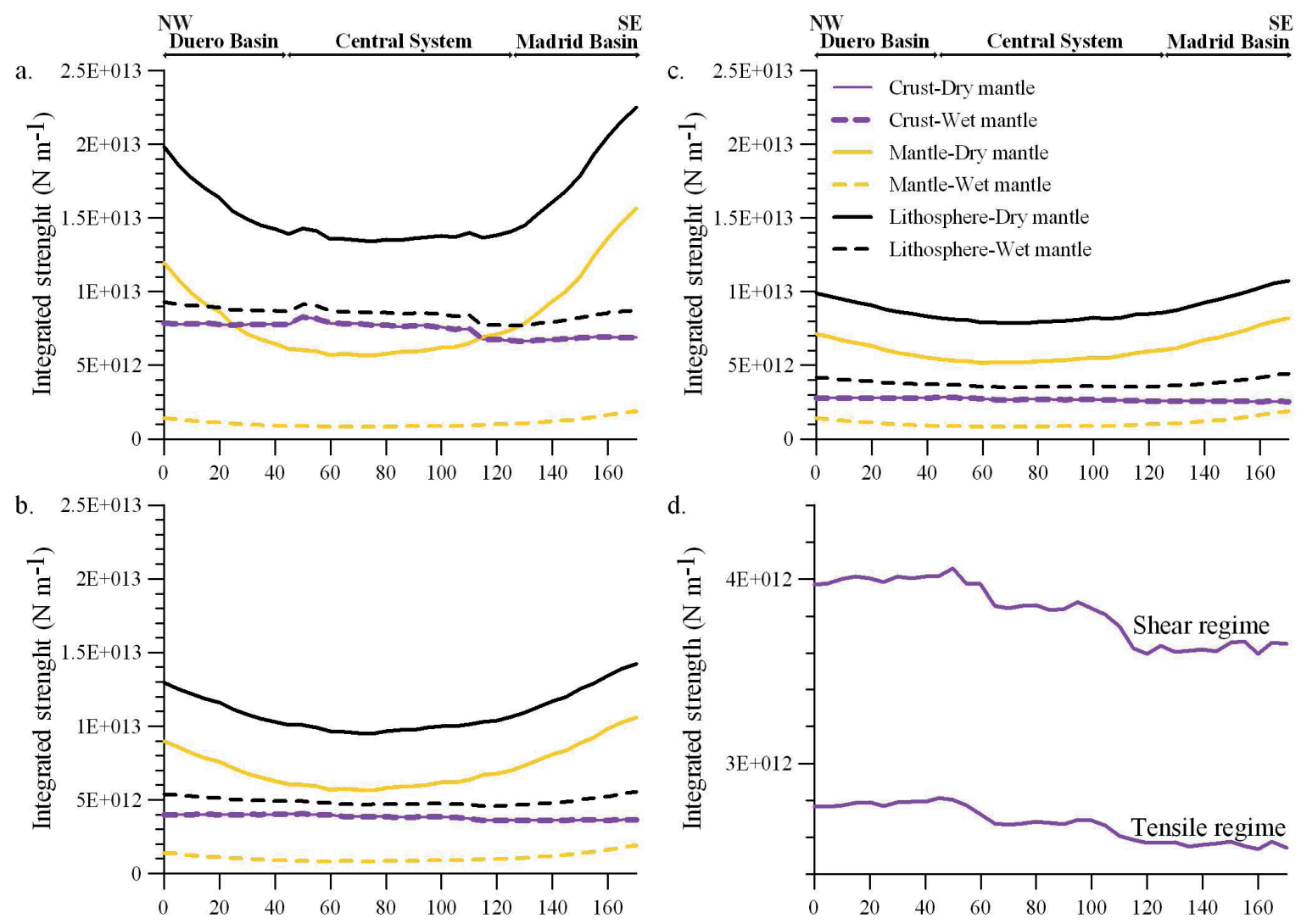

Fig. 5.- Integrated strength of the lithosphere, mantle and crust along the cross section with $\dot{\varepsilon}$ of $10^{-15} \mathrm{~s}^{-1}$ : (a) compressive regime, (b) shear regime, and (c) tensile regime. DM, dry lithospheric mantle; WM, wet lithospheric mantle. (d) Detailed crustal strength under shear $(\mathrm{SR})$ and tensile $(\mathrm{TR})$ regimes.

in the Central System under compression), while essential contribution comes from the crust with a wet rheology (Fig. $5)$. The integrated strength of the strong mantle is $2-3$ times the crustal one, whereas this range decreases to $0.2-0.8$ with the weak mantle. There is no solid evidence for the mantle composition in the peninsular centre (Villaseca and Orejana, 2008; Orejana et al., 2009), but taking into account that only strong mantles support the main geodynamic features and processes (Burov and Watts, 2006; Burov, 2009, 2011), the estimates obtained with a compressive regime or a wet peridotitic mantle must be dismissed. The weakening of the lithosphere under these conditions would hamper the Alpine deformations that shaped the Iberia interior. Nevertheless, a lithosphere with a dry mantle under shear or tensile regime would be stronger and consistent with the jelly sandwich model. Despite the complex stresses in Iberia, this result also agrees with the tectonic active regimes that mainly characterised its interior (Jiménez-Munt and Negredo, 2003; De Vicente et al., 2008; Olaiz et al.- 2009); consequently, strike-slip regime ( $\alpha$ in [3]) is the upper limit to estimate the brittle strength in this region.

\subsection{Cenozoic deformations}

From the above discussion, the integrated strength of the Iberian intraplate ranges from $9.5 \times 10^{12}$ to $1.4 \times 10^{13} \mathrm{~N} \mathrm{~m}^{-1}$ under shear, and from $7.9 \times 10^{12}$ to $1.1 \times 10^{13} \mathrm{~N} \mathrm{~m}^{-1}$ under tension. The $T_{e}$ in the range of $30-35 \mathrm{~km}$ is indicative of younger and warmer lithospheres (Caledonian, Variscan and Alpine orogenies) (Pérez-Gussinyé and Watts 2005). Both parameter estimates agree with the previous works (Van Wees et al. 1996; Tejero and Ruiz, 2002; Pérez-Gussinyé and Watts, 2005; Gómez-Ortiz et al., 2005b; Tesauro et al., 2007; Martín-Velázquez et al., 2008; Fernández et al., 2008; Jiménez-Díaz et al., 2012) and they decrease from the sedimentary basins toward the mountain range (Figs. 4b,c and $5 \mathrm{~b}, \mathrm{c})$. The spatial variations in rigidity are characteristic of the Iberian and European lithospheres (Pérez-Gussinyé and Watts, 2005; Tesauro et al., 2007). In the peninsular interior, they have been attributed to the inherited lithosphere structure and tectonic evolution owing to the absence of young thermal episodes (Gómez-Ortiz et al., 2005b). From the numerical modelling, the lithosphere of the Central System is weaker because of its lower mantle strength (as a result of the crust thickening) and its higher geotherm (due to the high heat production of granites). This is consistent with the Cenozoic uplift of the mountain range, which was conditioned by strength anisotropies resulting from contrasts of temperature and composition (Martín-Velázquez and De Vicente, 2012). Its weaker lithosphere with respect to that of the basins favoured its greater deformation. Furthermore, the biharmonic folding of the Iberian lithosphere (Cloetingh et al., 2002; De 

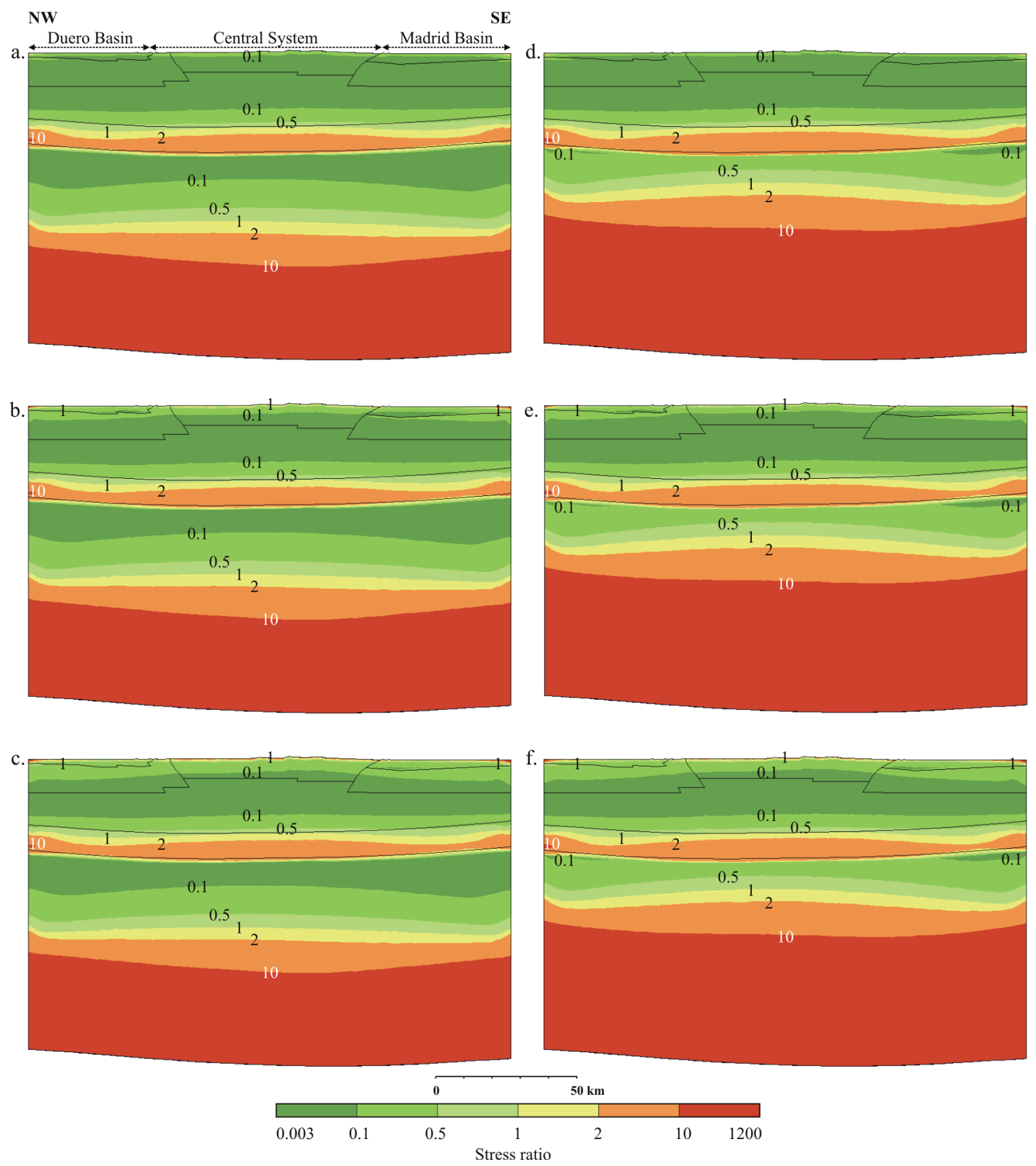

Fig. 6.- Stress ratios $R=\sigma_{e} / \sigma_{c}$ under a tectonic load of $10 \mathrm{MPa}$. Dry upper crust and mantle: (a) compressive regime, (b) shear regime, and (c) tensile regime. Dry upper crust and wet mantle: (d) compressive regime, (e) shear regime, and (f) tensile regime.

Vicente et al., 2007; Martín-Velázquez and De Vicente, 2012) is supported by the mechanical decoupling between crust and mantle that is obtained in the numerical modelling (Figs. 4b, $4 \mathrm{c}, 6 \mathrm{~b}, 6 \mathrm{c})$. Consequently, the current lithospheric strength in the Iberian intraplate is a continuation of the strength during the Cenozoic period.

Regarding the integrated crustal strength, there is a progressive decrease from the NW to the SE in shear and tensile regimes (Fig. 5d), parallel to the decrease in thickness of the competent crustal layer. The high tectonic activity recorded in the Madrid Basin during the Plio-Quaternary (De Vicente et al., 1996, 2007; Herraiz et al., 2000; Rodríguez-Pascua, 2005; Giner-Robles et al., 2012) could be related to its lower crustal strength. Moreover, the instrumental seismicity in the Madrid Basin is associated with NW-SE trending faults of strike-slip kinematics, while the NE-SW trending reverse faults are blocked as seismogenic sources (GinerRobles et al., 2012). Even though the relationship between seismicity and lithospheric strength is a fairly controversial subject (Sibson, 1986; Watts and Burov, 2003; Aldersons et al., 2003; Burov and Watts, 2006), the low crustal seismicity in the Duero Basin would be associated with its higher crustal strength while the increased nucleation of earthquakes in strike-slip faults in the Madrid Basin would be favoured by its lesser strength. 


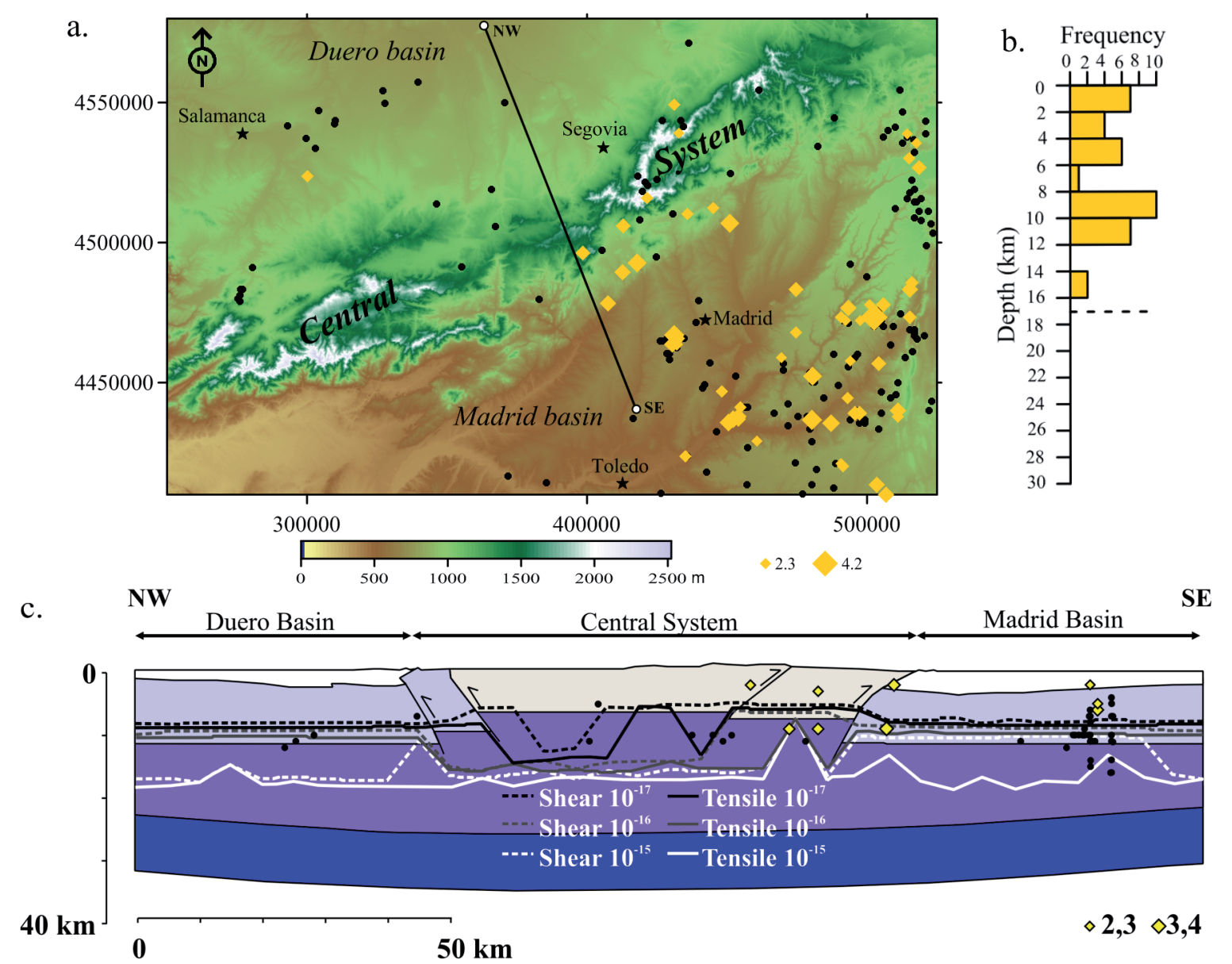

Fig. 7.- (a) Instrumental seismicity in 1954-2014 (272 earthquakes, black dots and yellow diamonds) on the digital elevation model of the peninsular centre (SRTM-90m; UTM Zone 30N). Yellow diamonds: 56 earthquakes with good quality (after 1985 and magnitudes greater than 2.2). (b) Hypocentral distribution of the 37 earthquakes with good quality and calculated depth. Dashed line: maximum seismogenic thickness estimated from 2D strength models (Fig. 4). (c) Simplified crustal cross section (location in Fig. 7a) with the projection of hypocentres that fall within a $50 \mathrm{~km}$ wide window in either side of the profile. Solid and dashed lines: seismogenic thickness under shear and tensile regimes with $\dot{\varepsilon}$ of $10^{-15}-10^{-17} \mathrm{~s}^{-1}$.

\subsection{Seismicity}

The strength to faulting provides a first order estimate of the stress that produces the frictional sliding in the crust, i.e. crustal seismicity (Sibson, 1986; Zoback and Townend, 2001; Watts and Burov, 2003; Aldersons et al., 2003). Seismicity in the interior of Iberia is low to moderate (De Vicente et al., 1996; Andeweg et al., 1999; Herraiz et al., 2000; Tejero and Ruiz, 2002; De Vicente et al., 2007, 2008; Giner-Robles et al., 2012). Seisms concentrate toward the SE of the Madrid Basin, owing to a flexural forebulge, and in basement faults at the southern edge of the Central System (Fig. 7a) (De Vicente et al., 1996; Andeweg et al., 1999; De Vicente et al., 2007; Giner-Robles et al., 2012).

In order to analyse the distribution of hypocentres, 272 events with calculated magnitude were compiled from the national seismic catalogue (IGN 2014) for the period 27/06/1954 to $10 / 08 / 2014$ (Fig. 7). Following the criteria proposed in CSN (2006), data prior to 1985 were ruled out (low quality of the network) as well as those with magnitudes less than
2.2 (elevated location errors). Only 37 of the remaining 56 earthquakes, with a maximum magnitude of 4.2 , had the hypocentral depth. Seismic activity mainly takes place in the upper levels of the crust (up to $16 \mathrm{~km}$ ) and it is bounded by the seismogenic thickness estimated from the brittle-ductile transition under strike-slip and normal fault regimes $\left(T_{s} \sim 17\right.$ $\mathrm{km})$. The type of stress regime does not produce large variations in $T_{\text {s }}$ (Fig. 7c), as was also observed in a similar study in the Gibraltar Arc area (Fernández-Ibáñez and Soto 2008). Although the first transition can be situated locally at lower depths $(\sim 8-10 \mathrm{~km})$, they correspond to a thin ductile sandwiched level (1 km thick) at the base of the upper crust under shear regime (mainly in Madrid Basin, Fig. 4b). Therefore, brittle deformation affects not only to the upper crust but also to the upper half of the middle crust. Previous strength envelopes under tension show two brittle-ductile transitions in the crust at 7-11 km and 13-16 km, with a well-developed ductile layer between them (3-4 km of thickness at 7-14 km), or one brittle-ductile transition at 9-10 km (Tejero and Ruiz, 2002; Jiménez-Díaz et al., 2012). The new strength models 
account for the whole hypocentral depths (Fig. 7b), and solve the problem of earthquakes within those previous ductile levels, which were attributed to uncertainties intrinsic to strength envelopes (Tejero and Ruiz, 2002). However, this discussion would remain open as the seismic layer may extend to greater depths than the brittle-ductile boundary (Scholz, 1998; Handy and Brun, 2004; Zang et al., 2007; Fernández-Ibáñez and Soto 2008; Chen et al., 2012). The cause of seismicity at ductile crustal levels is not well understood, and it has been explained by: high pore-fluid pressures that widens the brittle layer (Boncio, 2008; Brantut et al., 2011; Hirono and Tanikawa, 2011), increased strain rate in the co-seismic and early post-seismic phases (aftershocks) that would extend the brittle-ductile transition in depth (Boncio 2008; Chen et al., 2012), or alternative constitutive relationships such as brittle fracture mechanism (Zang et al., 2007), dislocation glide (Matysiak and Trepmann, 2012; White 2012), or mixed brittle-viscous region between the brittle upper crust and viscous lower crust where faults are able to penetrate (Scholz, 1998; Dempsey et al., 2012). On the other hand, there is a margin of error in the estimation of earthquake depths. The number of seismic stations or their distance to the hypocenters determine the location errors, so the available earthquake locations also may reflect depth errors.

The modelling of the tectonic load on the Iberian lithosphere (Fig. 6) shows that current permanent deformation occurs basically by creep in the lower crust and lower half of the mantle. The high strength values in the upper part of the mantle would prevent faulting in this region and just some super-

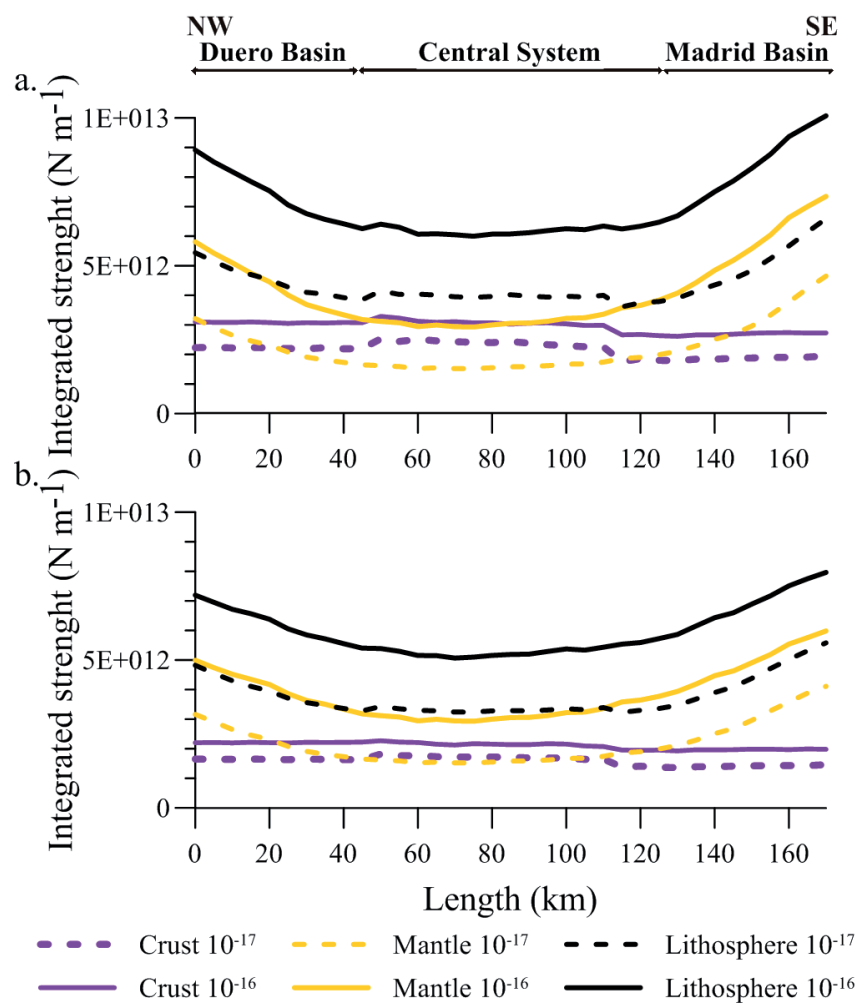

ficial areas could experience brittle deformation under tensile or shear regime. Therefore, although the intraplate Cenozoic deformations occurred in a compressive context, the shear to extensional conditions best describe the active tectonic regime, as also suggest the inversion of focal mechanisms (De Vicente et al., 2008; Olaiz et al., 2009) and the sedimentation of late Miocene alluvial fans (De Vicente and MuñozMartín, 2012). Earthquake nucleation are not resolved with these models but the elastic deformation, roughly coincident with the competent layers, and the aseismic creep in the crust and mantle explain the low seismicity of the peninsular centre. Moreover, the stress ratio of the elastic regions are low $(<0.5)$, and large stresses must build up to produce faulting/ seismicity.

Finally, the strength varies according to the strain rate, so that a strain rate decrease reduces $T_{s}$ and $T_{e}$ (FernándezIbáñez and Soto, 2008; Jiménez-Díaz et al., 2012). Tectonic strain rate in the Iberian Peninsula gradually changes from $10^{-15.5} \mathrm{~s}^{-1}$, near the plate boundary, to $10^{-17} \mathrm{~s}^{-1}$, toward the north (Jiménez-Munt and Negredo, 2003). The value commonly used in strength studies of the Iberia interior is $10^{-15}$ $\mathrm{s}^{-1}$ (Tejero and Ruiz, 2002; Jiménez-Díaz et al., 2012; also this work), but lower one for Europe $\left(10^{-16} \mathrm{~s}^{-1}\right.$, Tesauro et al., 2007). Owing to the wide range of $\dot{\varepsilon}$ and to check its effect, the integrated strength and the brittle-ductile transition has been modelled for $10^{-16} \mathrm{~s}^{-1}$ and $10^{-17} \mathrm{~s}^{-1}$ under shear and tensional regimes (Fig. 8). The basin lithospheres, except the south of the Duero Basin, are strong (jelly sandwich model) with those lower $\dot{\varepsilon}$, whereas the Central System lithosphere

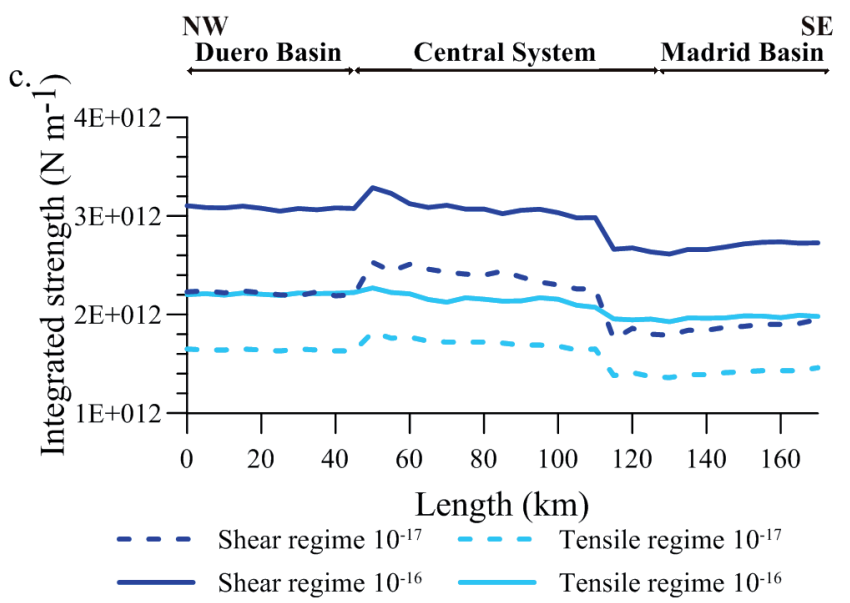

Fig. 8.- Integrated strength of the lithosphere, mantle and crust along the cross section with $\dot{\varepsilon}$ of $10^{-16}-10^{-17} \mathrm{~s}^{-1}$ : (a) shear regime and (b) tensile regime. (c) Detailed crustal strength under shear and tensile regimes. 
is strong only with $10^{-16} \mathrm{~s}^{-1}$ under extension, and the SE-NW increase in the integrated crustal strength is only observed with $10^{-16} \mathrm{~s}^{-1} . T_{\mathrm{s}}$ is mainly located in the upper crust $(\sim 9 \mathrm{~km})$ with $10^{-17} \mathrm{~s}^{-1}$ due to the development of thick ductile layers $(\sim 3 \mathrm{~km})$ in the basins (Fig. 7c). By increasing $\dot{\varepsilon}$ to $10^{-16} \mathrm{~s}^{-1}$, $T_{s}$ deepens $(\sim 10 / 15.6 \mathrm{~km}$ basins/Central System) and ductile layers reduce their thickness $(\sim 1.7 \mathrm{~km})$, better accounting for the seismicity. Consequently, a strong lithosphere with a crust weaker towards the SE, and in which the brittle layer extends to seismogenic depth, is only obtained with the highest value $10^{-15} \mathrm{~s}^{-1}$, as was initially modelled, or $10^{-16} \mathrm{~s}^{-1}$ under extension. This lower $\dot{\varepsilon}$ is more appropriate in this region far from the plate boundary and agrees with the work of Jiménez-Munt and Negredo (2003). The lithospheric strength and $T_{e}$ are reduced to $5.1-8 \times 10^{12} \mathrm{~N} \mathrm{~m}^{-1}$ and $25-30 \mathrm{~km}$ respectively under this slower strain rate. Steep gradients of $\dot{\varepsilon}$ by gravitational forces have been predicted under European mountain ranges with magnitudes comparable to tectonic $\dot{\varepsilon}$, and also in the peninsular centre but with gentle lateral changes (Tesauro et al.- 2011). Therefore, future research should also consider $\dot{\varepsilon}$ anisotropies to constrain this parameter and improve strength estimates of the lithosphere.

\section{Conclusions}

The lithospheric strength across the Central System mountain range and the Duero and Madrid sedimentary basins has been estimated reducing rheological uncertainties by a) constraining the crustal structure from a density model, b) only considering dry rheologies in the upper crust as Cenozoic deformation modelling suggests, and c) constraining the stress regime, mantle rheology and strain rate.

The deformation mechanism of the lithosphere is essentially brittle in the upper half of the crust and ductile in the lower half of the crust and mantle. A strong continental lithosphere, that allows its stability and the maintenance of the Central System reliefs, is obtained with a $\dot{\varepsilon}$ of $10^{-15} \mathrm{~s}^{-1}$, dry mantle, and strike-slip and tensional regimes, the stress conditions consistent with the active regimes in the Iberia centre. The effective elastic thickness $(30-35 \mathrm{~km})$ and the integrated lithospheric strength $\left(7.9 \times 10^{12}\right.$ to $\left.1.4 \times 10^{13} \mathrm{~N} \mathrm{~m}^{-1}\right)$ are typical of Phanerozoic lithospheres of Western Europe, and both parameters gradually increase from the Central System toward the Duero and Madrid basins. The crust-mantle decoupling, caused by the rheological stratification, and the strength heterogeneities determine the mountain range uplift and the biharmonic folding of the lithosphere during Alpine deformations. Although these conclusions are achieved with a $\dot{\varepsilon}$ of $10^{-15} \mathrm{~s}^{-1}$, similar results but with lower strength magnitudes $\left(25-30 \mathrm{~km}, 5.1-8 \times 10^{12} \mathrm{~N} \mathrm{~m}^{-1}\right)$ are also achieved under extension with $10^{-16} \mathrm{~s}^{-1}$, a more accurate value in the peninsular. The decrease of the integrated crustal strength from the Duero Basin to the Madrid Basin accounts for a parallel increase in recent tectonic activity and seismicity. The seismogenic thickness extends to the middle crust $(\sim 16-17 \mathrm{~km})$ and covers the instrumentally recorded hypocentral depths. However, the convergence between African-Eurasian plates is solved mainly by elastic deformation (upper-middle crust and upper part of the mantle) and ductile deformation (lower crust and lower part of the mantle), resulting in the low seismicity characteristic of the Iberian intraplate.

\section{Acknowledgements}

This research was partially supported by Consolider Ingenio 2006 Topo-Iberia CSD2006-00041. We are grateful to Loreto Antón for their comments on an earlier version of the manuscript, and two anonymous reviewers for provided helpful suggestions.

\section{References}

Afonso, J.C., Ranalli, G. (2004): Crustal and mantle strengths in continental lithosphere: is the jelly sandwich model obsolete? Tectonophysics 394, 221-232. doi:10.1016/j.tecto.2004.08.006.

Aldersons, F., Ben-Avraham, Z., Hofstetter, A., Kissling, E., AlYazjeen, T. (2003): Lower-crustal strength under the Dead Sea basin from local earthquake data and rheological modelling. Earth and Planetary Science Letters 214, 129-142. doi:10.1016/S0012821X(03)00381-9.

Alonso-Gavilán, G. I. Armenteros, J. Carballeira, A. Corrochano, P. Huerta, Rodríguez J.M. (2004): Cuencas cenozoicas. Cuenca del Duero. In: Vera, J.A. (ed.), Geología de España. SGE-IGME, Madrid, pp. 550-556.

Alonso-Zarza, A.M., Calvo, J.P., Silva, P.G., Torres, T. (2004): Cuencas cenozoicas. Cuenca del Tajo. In: Vera, J.A. (ed.), Geología de España. SGE-IGME, Madrid, pp. 556-559.

Ancochea, E. (2004): Canarias y el vulcanismo neógeno peninsular. El vulcanismo neógeno peninsular. La región volcánica de Campo de Calatrava. In: Vera, J.A. (ed.), Geología de España. SGE-IGME, Madrid, pp. 676-677.

Andeweg, B. (2002): Cenozoic tectonic evolution of the Iberian Peninsula: Effects and causes of changing stress fields. PhD Thesis, Vrije Universiteit, Amsterdam, 178 p.

Andeweg, B., De Vicente, G., Cloetingh, S., Giner, J., Muñoz Martín, A. (1999): Local stress fields and intraplate deformation of Iberia: variations in spatial and temporal interplay of regional stress sources. Tectonophysics 305, 153-164. doi:10.1016/S00401951(99)00004-9.

Banda, E., Suriñach, E., Aparicio, A., Sierra, J., Ruiz de la Parte, E. (1981): Crust and upper mantle structure of the central Iberian Meseta (Spain). Geophysical Journal of the Royal Astronomical Society 67, 779-789. doi:10.1111/j.1365-246X.1981.tb06954.x

Bea, F., Villaseca, C., Bellido, F. (2004): Macizo Ibérico. Zona Centroibérica. Magmatismo de la Zona Centroibérica. El Batolito de Ávila (Sistema Central Español). In: Vera, J.A. (ed.), Geología de España. SGE-IGME, Madrid, pp. 101-110.

Boncio, P. (2008): Deep-crust strike-slip earthquake faulting in southern Italy aided by high fluid pressure: insights from rheological analysis. Journal of the Geological Society 299, 195-210. doi:10.1144/SP299.12.

Brantut, N., Sulem, J., Schubnel, A. (2011): Effect of dehydration reactions on earthquake nucleation: Stable sliding, slow transients, and unstable slip. Journal of Geophysical Research 116, B05304. doi:10.1029/2010JB007876.

Burov, E.B. (2009): The equivalent elastic thickness (Te), seismic- 
ity and the long-term rheology of continental lithosphere: Time to burn-out "crème brûlée"? (insights from large-scale geodynamic modeling). Tectonophysics 484, 4-26.

Burov, E.B. (2011): Rheology and strength of the lithosphere. Marine and Petroleum Geology 28, 1402-1443. doi:10.1016/j.tecto.2009.06.013.

Burov, E.B., Diament, M. (1995): The effective elastic thickness (Te) of continental lithosphere: What does it really mean? Journal of Geophysical Research 100, 3905-3927. doi:10.1029/94JB02770.

Burov, E.B., Watts, A.B. (2006): The long-term strength of continental lithosphere: "jelly sandwich" or "crème brûlée"? GSA Today 16, 4-10. doi:10.1130/1052-5173(2006)016<4:TLTSOC $>2.0 . C O ; 2$.

Chen, W.P., Hung, S.H., Tseng, T.L., Brudzinski, M., Yang, Z., Nowack, R.L. (2012): Rheology of the continental lithosphere: Progress and new perspectives. Gondwana Research 21, 4-18. doi:10.1016/j. gr.2011.07.013.

Cloetingh, S., Burov, E., Beekman, F., Andeweg, B., Andriessen, P.A.M., Garcia-Castellanos, D., de Vicente, G., Vegas, R. (2002): Lithospheric folding in Iberia. Tectonics 1041. doi:10.1029/2001TC901031.

CSN (2006): Proyecto Prior. Determinación de fallas de Primer Orden mediante el análisis integrado de datos geológicos. Colección Otros Documentos, 15.2006, Consejo de Seguridad Nuclear, Madrid, $312 \mathrm{p}$.

De Bruijne, C.H., Andriessen, P.A.M. (2002): Far field effects of Alpine plate tectonism in the Iberian microplate recorded by fault related denudation in the Spanish Central System. Tectonophysics 349, 161-184. doi:10.1016/S0040-1951(02)00052-5.

De Vicente, G., Vegas, R. (2009): Large-scale distributed deformation controlled topography along the western Africa-Eurasia limit: Tectonic constraints. Tectonophysics 474, 124-143. doi:10.1016/j. tecto.2008.11.026.

De Vicente, G., Muñoz-Martín, A. (2012): The Madrid Basin and the Central System: A tectonostratigraphic analysis from $2 \mathrm{D}$ seismic lines. Tectonophysics 602, 259-285. doi:10.1016/j.tecto.2012.04.003

De Vicente, G., Giner, J.L., Muñoz-Martín, A., González-Casado, J.M., Lindo, R. (1996): Determination of present-day stress tensor and neotectonic interval in the Spanish Central System and Madrid Basin, central Spain: Dynamics of Extensional Basins and Inversion Tectonics. Tectonophysics 266, 405-424. doi:10.1016/S00401951(96)00200-4.

De Vicente, G., Vegas, R., Muñoz Martín, A., Silva, P.G., Andriessen, P., Cloetingh, S., González Casado, J.M., Van Wees, J.D., Álvarez, J., Carbó, A., Olaiz, A. (2007): Cenozoic thick-skinned deformation and topography evolution of the Spanish Central System. Global and Planetary Change 58, 335-381. doi:10.1016/j.gloplacha.2006.11.042.

De Vicente, G., Cloetingh, S., Muñoz Martín, A., Olaiz, A., Stich, D., Vegas, R., Galindo-Zaldívar, J., Fernández-Lozano, J. (2008): Inversion of moment tensor focal mechanisms for active stresses around the microcontinent Iberia: Tectonic implications. Tectonics 27, 1-22. doi:10.1029/2006TC002093.

Dempsey, D.E., Ellis, S.M., Rowland, J.V., Archer, R.A. (2012): The role of frictional plasticity in the evolution of normal fault systems. Journal of Structural Geology 39, 122-137. doi:10.1016/j. jsg.2012.03.001.

Fernández, J., Fernández, M., Miguelsanz, L., Camacho, A.G. (2008): On the interpretation of gravity tide residuals in the Iberian Peninsula. Journal of Geodynamics 45, 18-31. doi: 10.1016/j. jog.2007.03.006.

Fernàndez, M., Marzán, I., Correia, A., Ramalho, E. (1998): Heat flow, heat production, and lithospheric thermal regime in the Iberian Peninsula. Tectonophysics 291, 29-53. doi:10.1016/S0040-
1951(98)00029-8.

Fernàndez, M., Ranalli, G. (1997): The role of rheology in extensional basin formation modelling. Tectonophysics 282, 129-145. doi:10.1016/S0040-1951(97)00216-3.

Fernández-Ibáñez, F., Soto, J.I. (2008): Crustal rheology and seismicity in the Gibraltar Arc (western Mediterranean). Tectonics, 27. doi:10.1029/2007TC002192.

Giner-Robles, J.L., Pérez-López, R., Silva, P.G., Jiménez-Díaz, A., Rodríguez-Pascua, M.A. (2012): Recent tectonic model for the Upper Tagus Basin (central Spain). Journal of Iberian Geology 38, 113-126. doi:10.5209/rev JIGE.2012.v38.n1.39208.

Gölke, M., Coblentz, D. (1996): Origins of the European regional stress field. Tectonophysics 266, 11-24. doi:10.1016/S00401951(96)00180-1.

Gómez Ortiz, D. (2001): La estructura de la corteza en la zona central de la Península Ibérica. PhD Thesis, Universidad Complutense de Madrid, Madrid, $352 \mathrm{p}$.

Gómez-Ortiz, D., Tejero-López, R., Babín-Vich, R., Rivas-Ponce, A. (2005a): Crustal density structure in the Spanish Central System derived from gravity data analysis (Central Spain). Tectonophysics 403, 131-149. doi:10.1016/j.tecto.2005.04.006.

Gómez-Ortiz, D., Tejero, R., Ruiz, J., Babín-Vich, R., GonzálezCasado, J.M. (2005b): Estimating the effective elastic thickness of the lithosphere of the Iberian peninsula based on multitaper spectral analysis. Geophysical Journal International 160, 729-735. doi: 10.1111/j.1365-246X.2004.02499.x.

Handy, M.R., Brun, J.P. (2004): Seismicity, structure and strength of the continental lithosphere. Earth and Planetary Science Letters 223, 427-441. doi:10.1016/j.eps1.2004.04.021.

Herraiz, M., De Vicente, G., Lindo-Ñaupari, R., Giner, J., Simón, J.L., González-Casado, J.M., Vadillo, O., Rodríguez-Pascua, M.A., Cicuéndez, J.I., Casas, A., Cabañas, L., Rincón, P., Cortés, A.L., Ramírez, M., Lucini, M. (2000): The recent (upper Miocene to Quaternary) and present tectonic stress distributions in the Iberian Peninsula. Tectonics 19, 762-786. doi:10.1029/2000TC900006.

Hirono, T., Tanikawa, W. (2011): Implications of the thermal properties and kinetic parameters of dehydroxylation of mica minerals for fault weakening, frictional heating, and earthquake energetic. Earth and Planetary Science Letters 307, 161-172. doi:10.1016/j. eps1.2011.04.042.

IGN (2014): Servicio de información sísmica del Instituto Geográfico Nacional, http://www.ign.es/ign/layoutIn/sismoFormularioCatalogo.do, Date of reference: 14/08/2014.

ILIHA DSS Group (1993): A deep seismic sounding investigation of lithospheric heterogeneity and anisotropy beneath the Iberian Peninsula. Tectonophysics 221, 35-51. doi:10.1016/00401951(93)90026-G.

Jackson, J. (2002): Strength of the continental lithosphere: time to abandon the jelly sandwich? GSA Today 12, 4-10. doi:10.1130/10525173(2002)012<0004:SOTCLT $>2.0$. CO;2.

Jackson, J., McKenzie, D., Priestley, K., Emmerson, B. (2008): New views on the structure and rheology of the lithosphere. Journal of the Geological Society 165, 453-465. doi:10.1144/0016-76492007109.

Jiménez-Díaz, A., Ruiz, J., Villaseca, C., Tejero, R., Capote, R. (2012): The thermal state and strength of the lithosphere in the Spanish Central System and Tajo Basin from crustal heat production and thermal isostasy. Journal of Geodynamics 58, 29-37. doi:10.1016/j. jog.2012.01.005.

Jiménez-Munt, I., Negredo, A.M. (2003): Neotectonic modelling of the western part of the Africa-Eurasia plate boundary: from the Mid-Atlantic ridge to Algeria. Earth and Planetary Science Letters 205, 257-271. doi:10.1016/S0012-821X(02)01045-2.

Julià, J., Mejía, J. (2004): Thickness and Vp/Vs ratio variation in 
the Iberian Crust. Geophysical Journal International 156, 59-72. doi:10.1111/j.1365-246X.2004.02127.x.

Kohlstedt, D.L., Evans, B., Mackwell, S.J. (1995): Strength of the lithosphere: constraints imposed by laboratory experiments. Journal of Geophysical Research 100, 17587-17602. doi:10.1029/95JB01460.

Maggi, A., Jackson, J.A., McKenzie, D., Preistley, K. (2000): Earthquake focal depths, effective elastic thickness, and the strength of the continental lithosphere. Geology 28, 495-498. doi:10.1130/00917613(2000)28<495:EFDEET>2.0.CO;2.

Martín-Velázquez, S., De Vicente, G. (2012): The role of lithospheric heterogeneities in the location of the Cenozoic intraplate deformation of Iberia from finite element modelling. Tectonics 31. doi:10.1029/2011TC002954.

Martín-Velázquez, S., De Vicente, G., Elorza, F.J. (2008): Resistencia, espesor elástico efectivo y deformación de la litosfera Ibérica (Sistema Central y cuencas del Duero y Tajo). Geo-Temas 10, 15231526.

Martín-Velázquez, S., De Vicente, G., Elorza, F.J. (2009): Intraplate stress state from finite element modelling: The southern border of the Spanish Central System. Tectonophysics 473, 417-427. doi:10.1016/j.tecto.2009.03.024.

Matysiak, A.K., Trepmann, C.A. (2012): Crystal-plastic deformation and recrystallization of peridotite controlled by the seismic cycle. Tectonophysics 530-531, 111-127. doi:10.1016/j.tecto.2011.11.029.

Moisio, K., Kaikkonen, P. (2001): Geodynamics and rheology along the DSS profile SVEKA'81 in the central Fennoscandian Shield. Tectonophysics 340, 61-77. doi: 10.1016/S0040-1951(01)00147-0.

Moisio, K., Kaikkonen, P. (2004): The present day rheology, stress field and deformation along the DSS profile FENNIA in the central Fennoscandian Shield. Journal of Geodynamics 38, 161-184. doi:10.1016/j.jog.2004.06.003.

Olaiz, A.J., Muñoz-Martín, A., De Vicente, G., Vegas, R., Cloetingh, S. (2009): European continuous active tectonic strain-stress map. Tectonophysics 474, 33-40. doi:10.1016/j.tecto.2008.06.023.

Orejana, D., Villaseca, C., Pérez-Soba, C., López-García, J.A., Billström, K. (2009): The Variscan gabbros from the Spanish Central System: A case for crustal recycling in the sub-continental lithospheric mantle? Lithos 110, 262-276. doi:10.1016/j. lithos.2009.01.003.

Pérez-Gussinyé, M., Watts, A.B. (2005): The long-term strength of Europe and its implications for plate-forming processes. Nature 436, 381-384. doi:10.1038/nature03854.

Querol Müller, R. (1989): Geología del subsuelo de la Cuenca del Tajo. E.T.S.I. Minas, Universidad Politécnica de Madrid, Madrid, $48 \mathrm{p}$.

Racero Baena, A. (1988): Consideraciones acerca de la evolución geológica del margen NO de la cuenca del Tajo durante el Terciario a partir de los datos de subsuelo. II Congreso Geológico de España, Granada, España, 213-221.

Ranalli, G. (1995): Rheology of the Earth. Chapman and Hall, London, 413 p.

Ranalli, G., Murphy, D.C. (1987): Rheological stratification of the lithosphere. Tectonophysics 132, 281-295. doi:10.1016/00401951(87)90348-9.

Ribeiro, A., Kullberg, M.C., Kullberg, J.C., Manuppella, G., Phipps, S. (1990): A review of Alpine tectonics in Portugal: Foreland detachment in basement and cover rocks. Tectonophysics, $184357-$ 366. doi:10.1016/0040-1951(90)90448-H.

Rodríguez-Pascua, M.A. (2005): Estudios paleosismológicos en España: una revisión. Boletín Geológico y Minero 116, 203-216.
Ruiz, J., Gomez-Ortiz, D., Tejero, R. (2006): Effective elastic thicknesses of the lithosphere in the Central Iberian Peninsula from heat flow: Implications for the rheology of the continental lithospheric mantle. Journal of Geodynamics 41, 500-509. doi:10.1016/j. jog.2006.01.005.

Scholz, C.H. (1998): Earthquakes and friction laws. Nature 391, $37-$ 42. doi:10.1038/34097.

Sibson, R.H. (1986): Earthquakes and rock deformation in crustal fault zones. Annual Review of Earth and Planetary Sciences Journal 14, 149-175. doi:10.1146/annurev.ea.14.050186.001053.

Suriñach, E., Vegas, R. (1988): Lateral inhomogeneities of the Hercynian crust in central Spain. Physics of the Earth and Planetary Interiors 51, 226-234. doi:10.1016/0031-9201(88)90049-0.

Tejero, R., Perucha, M.A., Rivas, A., Bergamín, J.F. (1996): Modelos gravimétrico y estructural del Sistema Central. Geogaceta 20, $947-$ 950.

Tejero, R., Ruiz, J. (2002): Thermal and mechanical structure of the central Iberian Peninsula lithosphere. Tectonophysics 350, 49-62. doi:10.1016/S0040-1951(02)00082-3.

Tesauro, M., Kaban, M.K., Cloetingh, S.A.P.L., Hardebol, N.J., Beekman, F. (2007): 3D strength and gravity anomalies of the European lithosphere. Earth and Planetary Science Letters 263, 56-73. doi:10.1016/j.eps1.2007.08.035.

Tesauro, M., Burov, E.B., Kaban, M.K., Cloetingh, S.A.P.L. (2011): Ductile crustal flow in Europe's lithosphere. Earth and Planetary Science Letters 312, 254-265. doi:10.1016/j.eps1.2011.09.055.

Turcotte, D.L., Schubert, G. (2002): Geodynamics. Cambridge University Press, Cambridge, $456 \mathrm{p}$.

Van Wees, J.D., Cloetingh, S., De Vicente, G. (1996): The role of preexisting weak-zones in basin evolution: constraints from 2D finite element and 3D flexure models. Geological Society, London, Special Publications 99, 297-320. doi:10.1144/GSL.SP.1996.099.01.22.

Vegas, R., Vázquez, J.T., Suriñach, E., Marcos, A. (1990): Model of distributed deformation, block rotations and crustal thickening for the formation of the Spanish Central System. Tectonophysics 184, 367-378. doi:10.1016/0040-1951(90)90449-I.

Villaseca, C., Downes, H., Pin, C., Barbero, L. (1999): Nature and composition of the lower continental crust in central Spain and the granulite-granite linkage: inferences from granulitic xenoliths. Journal of Petrology 40, 1465-1496. doi:10.1093/petroj/40.10.1465.

Villaseca, C., Orejana, D. (2008): Rutilos ricos en Zr incluidos en granates de xenolitos granulíticos de la corteza inferior del Sistema Central Español: implicaciones geodinámicas. Geogaceta 44, 31 34.

Villaseca, C., Orejana, D., Pérez-Soba, C., Reyes, J. (2005): Estimación del régimen térmico y producción de calor de los niveles litosféricos del Sistema Central Español. Geogaceta 38, 215-218.

Watts, A.B., Burov, E.B. (2003): Lithospheric strength and its relationship to the elastic and seismogenic layer thickness. Earth and Planetary Science Letters 213, 113-131. doi:10.1016/S0012821X(03)00289-9.

White, J.C. (2012): Paradoxical pseudotachylyte - Fault melt outside the seismogenic zone. Journal of Structural Geology 38, 11-20. doi:10.1016/j.jsg.2011.11.016.

Zang, S.X., Wei, R.Q., Ning, J.Y. (2007): Effect of the brittle fracture on the rheological structure of the lithosphere and its applications in the Ordos. Tectonophysics 429, 267-285. doi:10.1016/j. tecto.2006.10.006.

Zoback, M.D., Townend, J. (2001): Implications of hydrostatic pore pressures and high crustal strength for the deformation of intraplate lithosphere. Tectonophysics 336, 19-30. doi:10.1016/S00401951(01)00091-9. 